OPEN ACCESS

Edited by:

Gianpiero Vigani,

University of Turin, Italy

Reviewed by:

Luca Brillante,

California State University,

United States

Silvia Quaggiotti,

University of Padua, Italy

Daniel H. Gonzalez,

National University of the Littoral,

Argentina

${ }^{*}$ Correspondence:

Youry Pil

youry.pii@unibz.it

Stefano Cesco

stefano.cesco@unibz.it

Specialty section This article was submitted to

Plant Nutrition,

a section of the journal

Frontiers in Plant Science

Received: 28 March 2019

Accepted: 08 July 2019

Published: 19 July 2019

Citation:

Marastoni L, Sandri M, Pii Y, Valentinuzzi F, Cesco $S$ and Mimmo T

(2019) Morphological Root Responses and Molecular Regulation of Cation Transporters Are Differently

Affected by Copper Toxicity and Cropping System Depending on the Grapevine Rootstock Genotype.

Front. Plant Sci. 10:946.

doi: 10.3389/fpls.2019.00946

\section{Morphological Root Responses and Molecular Regulation of Cation Transporters Are Differently Affected by Copper Toxicity and Cropping System Depending on the Grapevine Rootstock Genotype}

\author{
Laura Marastoni, Michele Sandri, Youry Piï, Fabio Valentinuzzi, Stefano Cesco* and \\ Tanja Mimmo
}

Faculty of Science and Technology, Free University of Bozen-Bolzano, Bolzano, Italy

The high copper $(\mathrm{Cu})$ concentration in vineyard soils causes the increase of $\mathrm{Cu}$ toxicity symptoms in young grapevines. Recently, intercropping of grapevine and oat was shown to reduce $\mathrm{Cu}$ toxicity effects, modulating the root ionome. On these bases, the focus of the work was to investigate the impact of $\mathrm{Cu}$ toxicity of either monocropped or oat-intercropped grapevine rootstocks plants (196.17 and Fercal), at both phenotypic (i.e., root architecture), and molecular (i.e., expression of transporters) levels. The results showed a different response in terms of root morphology that are both rootstock- and cropping system dependent. Moreover, the expression pattern of transporter genes (i.e., $V v C T r, V V N R A M P$, and $V V I R T 1$ ) in monocropped grapevine might resemble a $\mathrm{Mn}$ deficiency response induced by the excess of $\mathrm{Cu}$, especially in Fercal plants. The gene expression in intercropped grapevines suggested rootstock-specific response mechanisms, depending on Cu levels. In fact, at low Cu concentrations, Fercal enhanced both root system growth and transporter genes expression; contrarily, 196.17 increased apoplast divalent cations accumulation and transporters expression. At high $\mathrm{Cu}$ concentrations, Fercal increased the expression of all bivalent cation transporters and, as previously observed, enhanced the release of root exudates, whereas the 196.17 only modulated transporters. In conclusion, our results might suggest that the different adaptation strategies of the two rootstocks to $\mathrm{Cu}$ toxicity could be mainly ascribable to a fine-tuning of bivalent cations transporters expression at root level.

Keywords: grapevine, oat, copper, intercropping, gene expression, bivalent cations transporters

\section{INTRODUCTION}

The continuous application of copper $(\mathrm{Cu})$-based fungicides in viticulture is inducing an increase of $\mathrm{Cu}$ concentration in vineyard soils worldwide (Mackie et al., 2012). A survey carried out on vineyard soil on different European soil samples showed that $\mathrm{Cu}$ levels might be extremely variable, ranging from 350 to $690 \mathrm{mg} \mathrm{Cu} \mathrm{kg}^{-1}$, largely exceeding the limits imposed (Ruyters et al., 2013). 
Indeed, vineyard soil $\mathrm{Cu}$ contamination has already been reported in Italy, south France, and Germany (Deluisa et al., 1996; Ribolzi et al., 2002; Provenzano et al., 2010; El Azzi et al., 2013; Steinmetz et al., 2017). Grapevine plants, especially the young rootstocks featuring a shallow root apparatus, have to cope with the increasing metal concentration in soils and often exhibit symptoms of $\mathrm{Cu}$ toxicity. Copper is mainly accumulated in roots because its root-to-shoot translocation is rather limited (Adrees et al., 2015). As previously observed in Arabidopsis thaliana, high $\mathrm{Cu}$ concentrations (i.e., 10 and $50 \mu \mathrm{M} \mathrm{Cu}$ ) induced a reduction of the primary root growth and an increase of lateral roots development (Lequeux et al., 2010). The reduction of the root length due to $\mathrm{Cu}$ toxicity has also been reported in soybean (Glycine max; Lin et al., 2007), tomato (Solanum nigrum and Solanum lycopersicum Al Khateeb and Al-Qwasemeh, 2014), and grapevines (Ambrosini et al., 2015). Moreover, high levels of $\mathrm{Cu}$ induced root darkening, a thickening of root tips and a reduction of root hairs (Juang et al., 2012).

The uptake of $\mathrm{Cu}$ in plants is mediated by a family of specific transporters, known as Copper Transporter CTr or COPT gene family. This gene family has already been identified in different plant species and it is formed by a variable number of genes; for example in A. thaliana (Sancenón et al., 2003) and Vitis vinifera (Martins et al., 2014) five and eight members of the COPT gene family have been identified, respectively. Some pieces of evidence reported that $\mathrm{Cu}$ can be also taken up by other bivalent cations transporters, as the Natural Resistance Associated Macrophage Proteins (NRAMP), Zrt- and Irt-like proteins (ZIP), and Iron Related Transporters (IRT) (Wintz et al., 2003; Yruela, 2005; Tsai and Schmidt, 2017). Indeed, IRT has been firstly identified for $\mathrm{Fe}$ (II) uptake and, depending on the isoform, for $\mathrm{Zn}$ uptake. The IRT-mediated $\mathrm{Cu}$ uptake is still controversial. In fact, $A$. thaliana IRT1 is not able to mediate $\mathrm{Cu}$ transport (Korshunova et al., 1999), whilst both tomato LeIRT1 and LeIRT2 can transport $\mathrm{Cu}$ (Eckhardt et al., 2001). On the other hand, NRAMP have been identified as manganese (Mn), iron (Fe), and $\mathrm{Zn}$ transporters (Thomine et al., 2000), whilst NRAMP-mediated $\mathrm{Cu}$ uptake has been proved only in mice (Gunshin et al., 1997). Therefore, CTr transporters are the only one specific for $\mathrm{Cu}$ transport (Yuan et al., 2011); nonetheless, $\mathrm{Cu}$ can also share the uptake pathway with other micronutrients such as $\mathrm{Fe}, \mathrm{Mn}$, and $\mathrm{Zn}$, via the activity of the abovementioned bivalent cation transporters. Consistently, when $\mathrm{Cu}$ is available at high concentrations, it can compete with the uptake of other micronutrients. Marastoni et al. (2019) reported that high $\mathrm{Cu}$ concentrations (i.e., 25 and $50 \mu \mathrm{M} \mathrm{Cu}$ ) could affect $\mathrm{Mn}, \mathrm{Zn}$, and $\mathrm{Fe}$ concentrations in grapevine plant tissues (Marastoni et al., 2019); in addition, the effects provoked by $\mathrm{Cu}$ toxicity on micronutrients (i.e., $\mathrm{Mn}$ and $\mathrm{Zn}$ ) concentrations were dependent on the rootstock genotype (i.e., Fercal and 196.17). In particular, the symplastic Mn concentration in root tissue was reduced in Fercal plants, whilst not altered in 196.17 rootstock with increasing $\mathrm{Cu}$ concentrations.

Different agronomic practices have been studied to reduce the effects of $\mathrm{Cu}$ toxicity improving also the plant nutritional status. Positive effects were reported by Baldi et al. (2018), who proposed the use of phosphate fertilizers to reduce the effects of Cu toxicity on grapevine, while Juang et al. (2014) studied the effects of magnesium $(\mathrm{Mg})$ nutrition in reducing $\mathrm{Cu}$ toxicity symptoms. Moreover, also liming was suggested in order to reduce grapevine $\mathrm{Cu}$ toxicity symptoms (Ambrosini et al., 2015), obtained by a reduction of $\mathrm{Cu}$ concentration in soil solution and an increase in $\mathrm{Mg}$ and calcium ( $\mathrm{Ca}$ ) plant uptake, restoring root morphology. The intercropping is also known to improve the resource-use efficiency of crops (Cesco et al., 2006; Brooker et al., 2014; Li et al., 2014) and/or prevent metal toxicity of beneficiary plants (Simões et al., 2012; Brooker et al., 2014; Walker et al., 2014). In particular, our previous study showed how the intercropping of grapevine plants with oat might mitigate $\mathrm{Cu}$ toxicity symptoms (Marastoni et al., 2019). The two rootstocks used, Fercal and 196.17, were obtained from the same parental cross (i.e., Vitis vinifera $\times$ Vitis berlandieri), albeit showing a different adaptation to diverse soil conditions; Fercal displays a good tolerance to calcareous soils (i.e., alkaline $\mathrm{pH}$ ), whilst 196.17 performs better in acidic soils ${ }^{1}$. Interestingly, in these two dramatically different $\mathrm{pH}$ conditions of the soils, also the availability of $\mathrm{Cu}$ is influenced, implying that the two rootstocks might feature diverse tolerance strategies to excessive $\mathrm{Cu}$ concentrations in the growth substrate. In the intercropping experiment, the two rootstocks were differentially affected by the presence of oat, with Fercal performing better than the 196.17. Even the root ionome was modified by the intercropping, and Fercal was reported to better balance root symplast nutrient concentration compared with the 196.17 rootstock (Marastoni et al., 2019).

The different behavior of Fercal and 196.17 rootstocks when exposed to $\mathrm{Cu}$ toxicity and/or grown in association with graminaceous plants as oat (i.e., intercropping) suggests that these rootstocks are characterized by different detoxification and competition mechanisms. To elucidate these differences and peculiarities we performed a study combining the alterations of root morphology, $\mathrm{Cu}$ concentrations in roots, and shoots with the expression of key genes involved in the uptake of bivalent cations, since both $\mathrm{Mn}$ and Fe have shown to have antagonistic and/or synergistic effects with $\mathrm{Cu}$ in two grapevine rootstocks (Fercal and 196.17; Marastoni et al., 2019). The ultimate aim of this work was thus to create a possible $\mathrm{Cu}$ root uptake model for the two grapevine rootstocks in function of $\mathrm{Cu}$ toxicity and the agricultural practices (i.e., intercropping vs. monocropping).

\section{MATERIALS AND METHODS}

\section{Plant Material and Growth Conditions}

Plant material and growing conditions were conducted as previously described (Marastoni et al., 2019). Briefly, two grapevine rootstocks, Fercal and 196.17 (both Vitis vinifera $\times$ Vitis berlandieri) were provided as small soil-grown cuttings. Plants were removed from soil, roots were carefully cleaned with tap water and subsequently grown in a hydroponic system ( $1.5 \mathrm{~L}$ pots). After 14 days of acclimation in a full nutrient solution $\left[\mathrm{Ca}\left(\mathrm{NO}_{3}\right)_{2} 2 \mathrm{mM}, \mathrm{KCl} 0.1 \mathrm{mM}, \mathrm{KH}_{2} \mathrm{PO}_{4} 0.1 \mathrm{mM}\right.$, $\mathrm{K}_{2} \mathrm{SO}_{4} 0.1 \mathrm{mM}, \mathrm{MgSO}_{4} 0.5 \mathrm{mM}, \mathrm{H}_{3} \mathrm{BO}_{3} 10 \mu \mathrm{M}, \mathrm{MnSO}_{4} 0.5 \mu \mathrm{M}$,

${ }^{1}$ http://www.vivairauscedo.com/portinnesti 
$\mathrm{CuSO}_{4} \quad 0.2 \mu \mathrm{M}, \mathrm{ZnSO}_{4} \quad 0.5 \mu \mathrm{M}\left(\mathrm{NH}_{4}\right)_{6} \mathrm{Mo}_{7} \mathrm{O}_{24} 0.01 \mu \mathrm{M}$, and NaFeEDTA $80 \mu \mathrm{M}$ ] plants were transferred to nutrient solutions supplied with four different $\mathrm{Cu}$ concentrations (0.25-25-50 $\mu \mathrm{M}$ ) for additional 14 days (five biological replicates for each $\mathrm{Cu}$ treatment). Copper was provided as $\mathrm{CuSO}_{4} \cdot 5 \mathrm{H}_{2} \mathrm{O}$ (Sigma-Aldrich) and the concentration of $0.2 \mu \mathrm{M}$ was used as control. The composition of the nutrient solution during the treatment was designed following Bravin et al. (2010): briefly, $\mathrm{KH}_{2} \mathrm{PO}_{4}$ concentration was reduced to $0.05 \mathrm{mM}$ and the $\mathrm{pH}$ was buffered at 6 with 2-( $N$-morpholino)ethanesulfonic acid (MES)-KOH $1 \mathrm{mM}$. The nutrient solutions were continuously aerated and replaced every 3-4 days. Plants were grown in a climatic chamber with a light $\left(220 \mu \mathrm{mol} \mathrm{m}{ }^{-2} \mathrm{~s}^{-1}\right) /$ dark period of $14 / 10 \mathrm{~h}$ at $70 \% \mathrm{RH}$.

Both grapevine rootstocks were either grown hydroponically alone (monocropped) or intercropped with oat plants (Avena sativa L. cv Fronteira). For the intercropped samples, oat plants were first germinated on a $\mathrm{CaSO}_{4} 0.5 \mathrm{mM}$ moist paper for 5 days in the dark, then transferred to a hydroponic system with $\mathrm{CaSO}_{4}$ $0.5 \mathrm{mM}$ for $24 \mathrm{~h}$ to repair possible cell lesions (Hawkesford et al., 2012) and afterward to the full nutrient solution for 6 days. Oat plants were then transferred into pots containing the grapevine rootstocks (15 oat plants per grapevine plant). After 14 days in a full nutrient solution, plants were transferred to nutrient solutions supplied with different $\mathrm{Cu}$ concentrations as described above and grown for another 14 days.

\section{Root Morphology and Cu Composition of Plant Tissues}

At harvest, root morphology parameters (total root length, number of tips, root volume, and average root diameter) were determined using the Winrhizo software (EPSON1680, WinRHIZO Pro2003b, Regent Instruments Inc., Quebec, Canada). Afterward, the roots and leaves were separated and dried at $65^{\circ} \mathrm{C}$ until constant weight was reached, a portion of the root apparatus was frozen in liquid nitrogen and kept at $-80^{\circ} \mathrm{C}$ for gene expression analysis. Roots and leaves tissues were acid digested $\left(\mathrm{HNO}_{3} 65 \% \mathrm{v} / \mathrm{v}\right)$ in a single digestion chamber (SRC) microwave digestion system (UltraWAVE, Milestone, Shelton, CT, United States) and the $\mathrm{Cu}$ concentration was determined by Inductively Coupled Plasma Optical Emission Spectroscopy (ICP-OES, Arcos Ametek Spectro, Germany).

\section{Transporter Gene Sequences Identification}

The putative grapevine orthologous genes of NRAMP were obtained through a bioinformatics analysis. The amino acidic sequences of AtNRAMP (Thomine et al., 2000) and OsNRAMP (Takahashi et al., 2011) gene families were used to perform a BlastP analysis using the CRIBI grapevine genome browser ${ }^{2}$. NRAMP are characterized by 12 transmembrane domains (Takanashi et al., 2014), thus the grapevine sequences were screened for the number of transmembrane domains. The prediction of the transmembrane domain was performed with

${ }^{2}$ http://genomes.cribi.unipd.it/grape/
Tmap software (Persson and Argos, 1994). The matching proteins were then screened for phylogenetic relationship between the identified genes and orthologous with DDBJ ClustalW software. The tree visualization was performed with FigTree version 1.4.3. The $V v C T r$ genes sequences were obtained by Martins et al. (2012a,b), whereas the VvIRT1 sequence was obtained by Vannozzi et al. (2017).

\section{Real-Time RT PCR}

The RNA extraction was performed using Spectrum Plant Total RNA Kit (Sigma-Aldrich) after grinding the root tissues in liquid nitrogen. The quality and purity of the samples were obtained spectrophotometrically and by electrophoresis. Then $1 \mu \mathrm{g}$ of total RNA was subjected to DNAse digestion with $10 \mathrm{U}$ of DNAse RQ1 (Promega) and cDNA was synthetized using ImProm-II Reverse Transcription System (Promega). The amplification primers were designed to be $20 \mathrm{bp}$ long and to obtain an amplicon of 100 bp (Supplementary Table S1). The Elongation Factor $1 \alpha$ and Tubulin housekeeping primers were obtained from Pii et al. (2014). The Real-Time Reverse Transcriptase PCR (Real-Time RT PCR) was performed using the SsoFast EvaGreen Supermix (Bio-Rad) and the Qiagen Rotor Gene Q real-time PCR. The relative expression and the standard error was calculated according to Pfaffl et al. (2002). The amplification efficiency was calculated using LinRegPCR (Ramakers et al., 2003).

\section{Statistical Analysis}

The quantitative analyses have been run on at least three independent biological replicates; for each biological replicate, the quantitative analyses have been run with three technical repetitions. Statistical significance were tested performing Student's $t$-test and one way ANOVA using GraphPad Prism 5.00.288 for Windows, GraphPad Software, San Diego, CA, United States.

\section{RESULTS}

\section{Root Morphology and Architecture}

The high $\mathrm{Cu}$ concentrations affected the root morphology of both grapevine rootstocks, particularly Fercal, and oat plants (Figures 1-4), albeit to different extent. In particular, a darkening of the roots was observed with increasing $\mathrm{Cu}$ concentrations in both grapevine rootstocks independently from the growing condition (Figures 1, 2). Furthermore, $\mathrm{Cu}$ caused a thickening and a modification of the structure (bumping surface) of root tips (Supplementary Figure S1). This $\mathrm{Cu}$ toxicity symptom was visible only in $25 \mu \mathrm{M}$ Cu-treated Fercal plants grown in both monocropping and intercropping systems (Figure 1). Differently, monocropped 196.17 rootstock showed a root tips modification when exposed to 5 and $25 \mu \mathrm{M}$ of $\mathrm{Cu}$, whilst the intercropped rootstocks displayed the same symptoms at the highest $\mathrm{Cu}$ concentrations (i.e., 25 and $50 \mu \mathrm{M}$ ) (Figure 2). Furthermore, the concentration of $50 \mu \mathrm{M} \mathrm{Cu}$ in the nutrient solutions led to necrotic roots in all the growing conditions in both rootstocks (Figures 1, 2). 


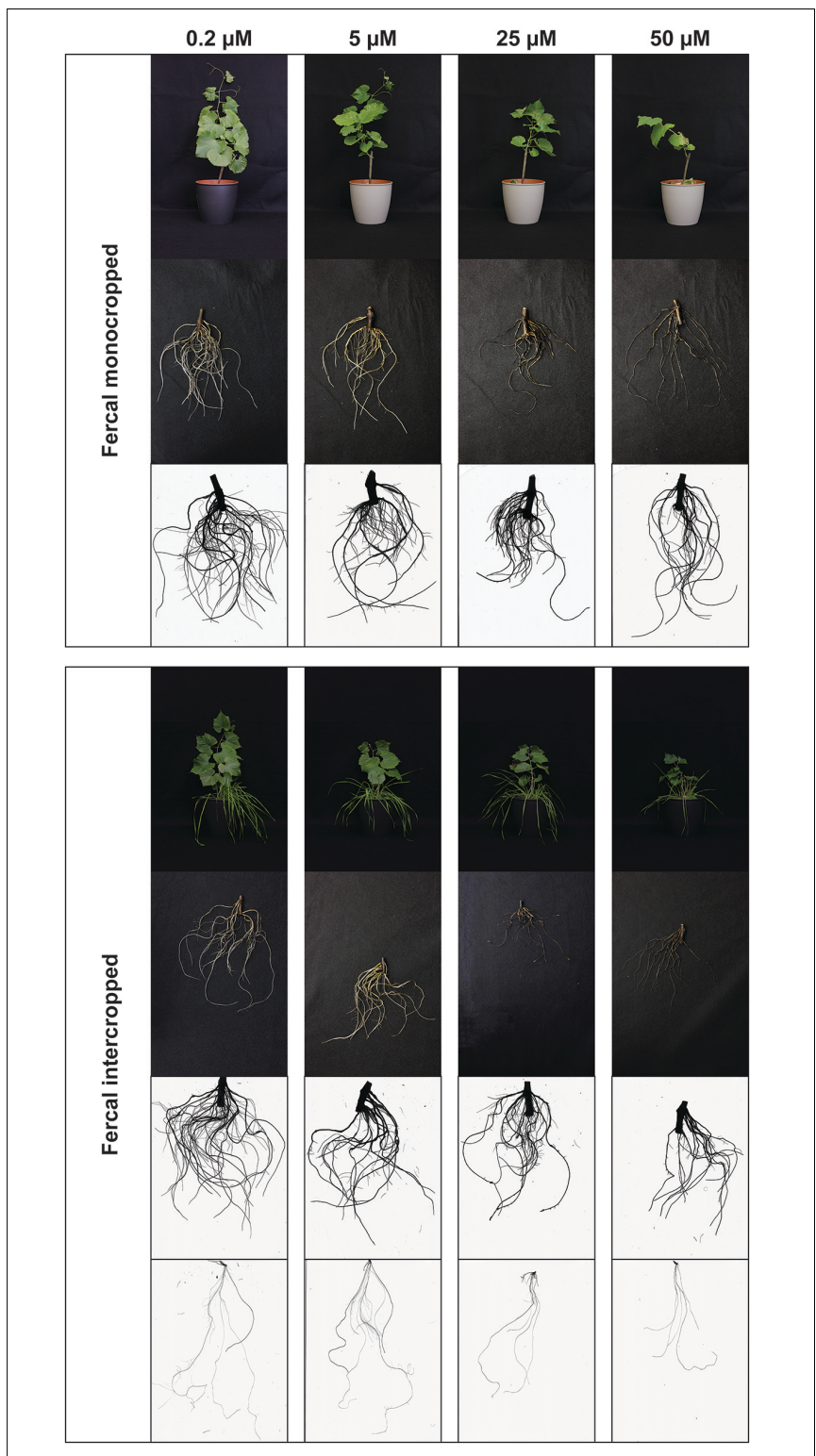

FIGURE 1 | Phenotype of Fercal rootstock plants grown at different $\mathrm{Cu}$ concentrations. Representative pictures of Fercal rootstocks (shoots, roots, and a representative WinRhizo Scan of the root apparatus) in both growing conditions (mono- and intercropping) at different concentrations of $\mathrm{Cu}$ (0.2-5-25-50 $\mu \mathrm{M})$. When presenting intercropping condition, also a representative WinRhizo Scan of oat root apparatus is shown. Pictures have been taken at harvest, i.e., 14 days after Cu treatment.

The root architecture of monocropped Fercal rootstocks treated with 25 and $50 \mu \mathrm{M} \mathrm{Cu}$ revealed a decreased root length and number of root tips compared to the control (Figures 3A,B). Although intercropped Fercal rootstocks grown at 25 and $50 \mu \mathrm{M}$ $\mathrm{Cu}$ showed a decreased root length compared to the control, the number of tips was not modified by the increasing $\mathrm{Cu}$ concentrations (Figures $\mathbf{3 A}, \mathbf{B}$ ) In addition, the surface area decreased in mono- and intercropped Fercal plants cultivated at 25 and $50 \mu \mathrm{M} \mathrm{Cu}$. However, when comparing mono- and

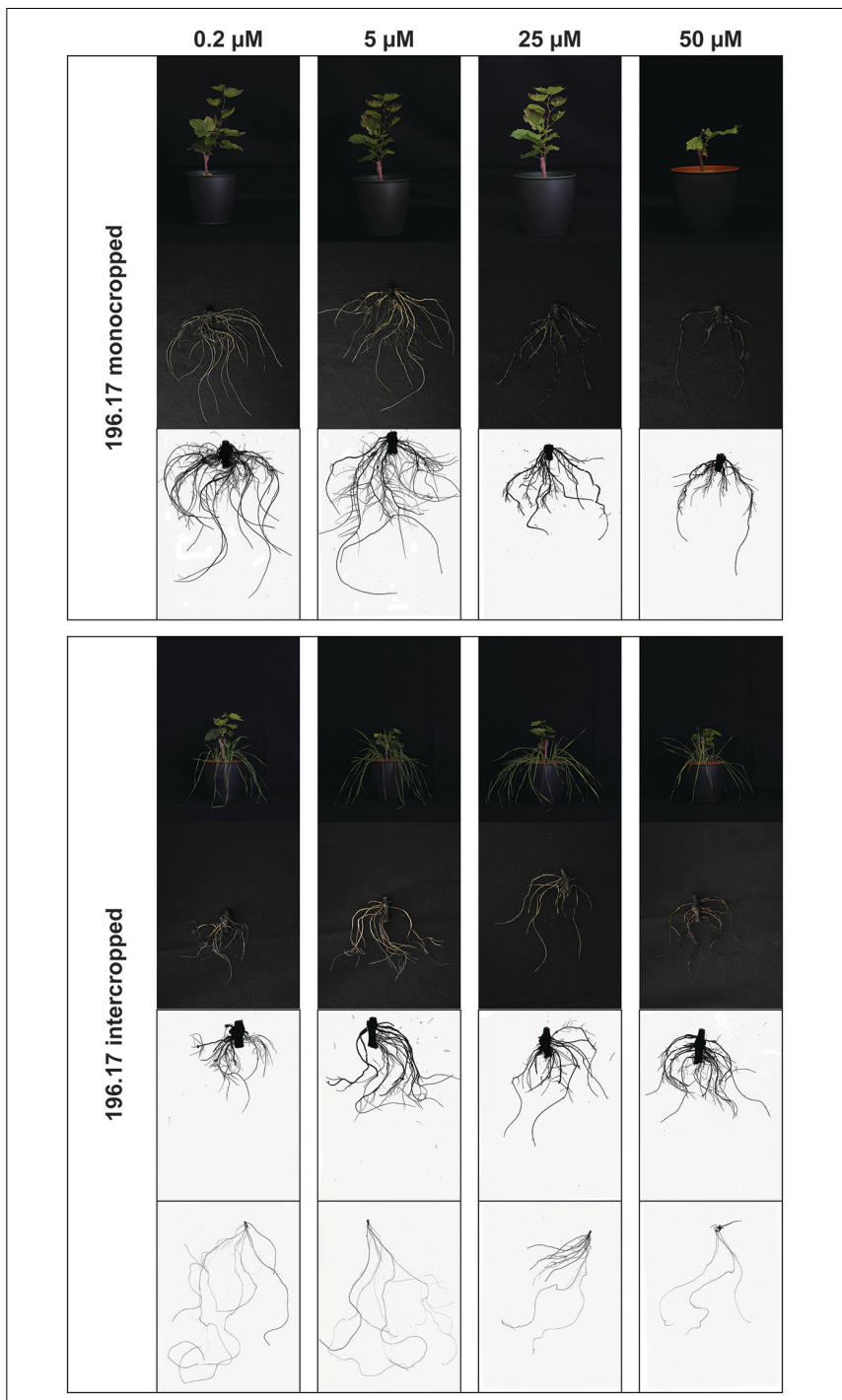

FIGURE 2 | Phenotype of 196.17 rootstock plants grown at different Cu concentrations. Representative pictures of 196.17 rootstocks (shoots, roots, and a representative WinRhizo Scan of the root apparatus) in both growing conditions (mono- and intercropping) at different concentrations of $\mathrm{Cu}$ (0.2-5-25-50 $\mu \mathrm{M})$. When presenting intercropping condition, also a representative WinRhizo Scan of oat root apparatus is shown. Pictures have been taken at harvest, i.e., 14 days after Cu treatment.

intercropped Fercal plants, within each $\mathrm{Cu}$ concentrations used in the experiment, any statistically significant difference in root length, number of tips and root surface area could be highlighted (Figure 3). Moreover, no differences of root morphology parameters of both mono- and intercropped 196.17 rootstocks were observed with increasing $\mathrm{Cu}$ concentrations (Figure 3).

Comparing the two rootstocks, in control conditions $(0.2 \mu \mathrm{M}$ $\mathrm{Cu}$ ) intercropped 196.17 rootstocks showed a significant decrease in the root length and in the root surface area as compared to intercropped Fercal (Figures 3A,D). At $50 \mu \mathrm{M}$ $\mathrm{Cu}$, monocropped Fercal reported a higher root diameter compared to the monocropped 196.17, whilst no differences 
A

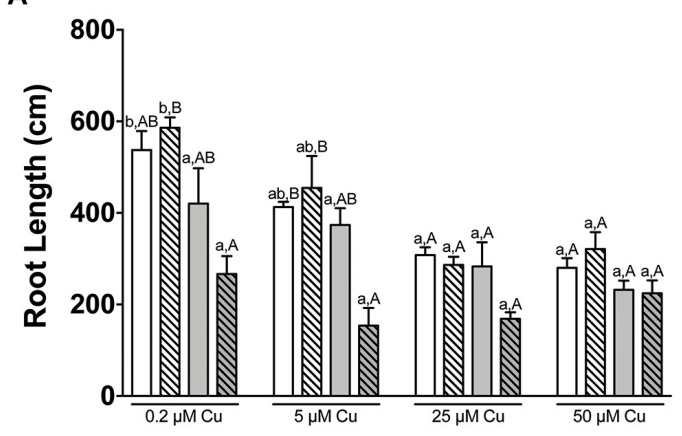

C

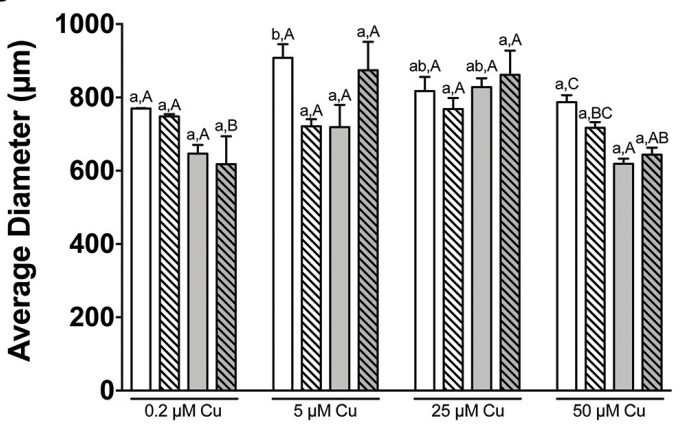

Fercal monocropped

$\mathbb{Q}$ Fercal intercropped
B

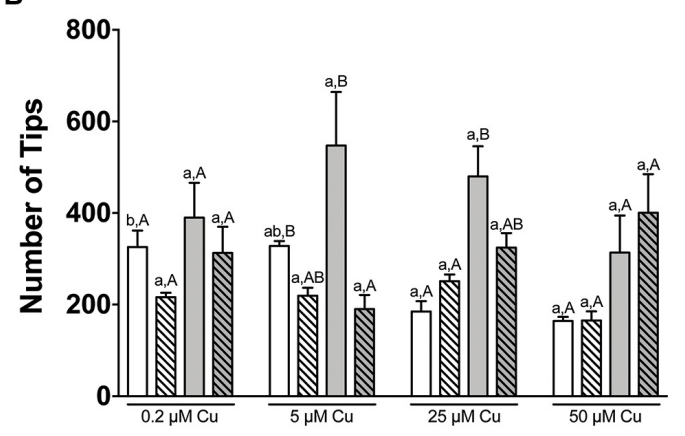

D

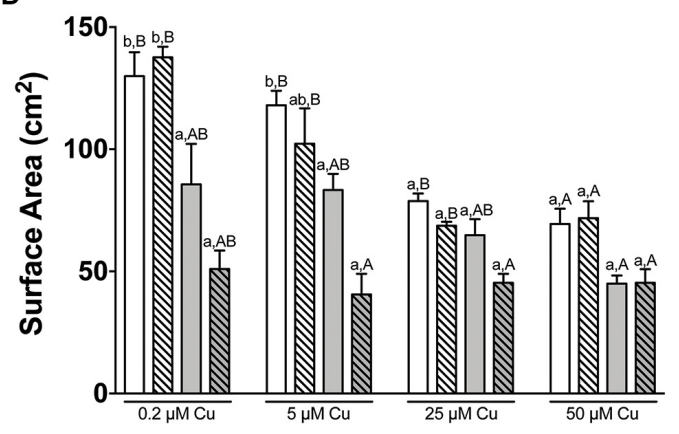

196.17 monocropped

196.17 intercropped

FIGURE 3 | Root architecture parameters of Fercal and 196.17 rootstock plants, either monocropped or intercropped with oat, ad exposed to increasing concentration of $\mathrm{Cu}$. (A) Total root length. The statistical significance of the whole dataset was tested by a three-way ANOVA test: Cu concentration $p<0.0001$; Genotype $p<0.0001$; Cropping system $p=0.0155$; Cu concentration $\times$ Genotype $p=0.0189$; Cu concentration $\times$ Cropping system $p=0.2533$;

Genotype $\times$ Cropping system $p=0.0002$; Cu concentration $\times$ Genotype $\times$ Cropping system $p=0.2004$. (B) Total number of tips. The statistical significance of the whole dataset was tested by a three-way ANOVA test: Cu concentration $p=0.3870$; Genotype $p<0.0001$; Cropping system $p=0.0033$; Cu concentration $\times$ Genotype $p=0.3179$; Cu concentration $\times$ Cropping system $p=0.0051$; Genotype $\times$ Cropping system $p=0.1043$; Cu

concentration $\times$ Genotype $\times$ Cropping system $p=0.0617$. (C) Average diameter. The statistical significance of the whole dataset was tested by a three-way ANOVA test: Cu concentration $p<0.0001$; Genotype $p=0.0107$; Cropping system $p=0.3830$; Cu concentration $\times$ Genotype $p=0.0063$; Cu concentration $\times$ Cropping system $p=0.9896$; Genotype $\times$ Cropping system $p=0.0025$; Cu concentration $\times$ Genotype $\times$ Cropping system $p=0.0229$. (D) Total surface area. The statistical significance of the whole dataset was tested by a three-way ANOVA test: Cu concentration $p<0.0001$; Genotype $p<0.0001$; Cropping system $p=0.0008$; Cu concentration $\times$ Genotype $p=0.0003$; Cu concentration $\times$ Cropping system $p=0.0681$; Genotype $\times$ Cropping system $p=0.0132$; Cu

concentration $\times$ Genotype $\times$ Cropping system $p=0.2807$. Data have been collected at harvest (14 days after Cu treatment) and are reported as means ( \pm SE), $n=5$. Different letters indicate significantly different values as determined using one-way ANOVA with Tukey post hoc tests ( $p<0.05)$. Lower-case letters account for statistical analyses of the same cropping system exposed to different Cu concentrations. Upper-case letters account for statistical analyses of the different cropping system exposed to the Cu concentration.

were detected in the root length, in the number of tips and in the surface area (Figure 3). On the other hand, at $25 \mu \mathrm{M} \mathrm{Cu}$ Fercal rootstocks, regardless mono- and intercropping growing system, displayed a lower number of tips and a higher surface area as compared to mono- and intercropped 196.17 rootstock (Figures 3B,D).

Oat plants reduced their root length, number of tips and root surface at high $\mathrm{Cu}$ concentrations (i.e., 25 and $50 \mu \mathrm{M}$ $\mathrm{Cu}$ ) independently from the rootstock they are intercropped with (Figure 4). However, at $25 \mu \mathrm{M} \mathrm{Cu}$ both the number of tips and the surface area of Fercal-intercropped oat are lower than those detected in 196.17-intercropped oat plants (Figures 4B,D). This difference was not present at $50 \mu \mathrm{M} \mathrm{Cu}$, however, oat plants grown at this $\mathrm{Cu}$ concentration showed an increased root diameter independently from the intercropped rootstock (Figure 4C).

\section{Cu Concentration in Plant Tissues}

As expected, $\mathrm{Cu}$ accumulation in plant tissues followed the increasing $\mathrm{Cu}$ concentration in the nutrient solution in all growing conditions of both Fercal and 196.17 rootstocks (Figure 5). The roots were the main targets for $\mathrm{Cu}$ accumulation. In fact, $\mathrm{Cu}$ translocation to the shoots was very limited, being the $\mathrm{Cu}$ concentration up to 700 -fold lower than in the grapevine roots treated with 25 and $50 \mu \mathrm{M} \mathrm{Cu}$ (Figure 5). Furthermore, the $\mathrm{Cu}$ increase was more pronounced for the root tissues (Fercal: $+1109,8193,5871 \%$, and 196.17: $+276,6100$, and $19508 \%$ vs. the control at 5, 25, and $50 \mu \mathrm{M}$, respectively) compared to the shoot 

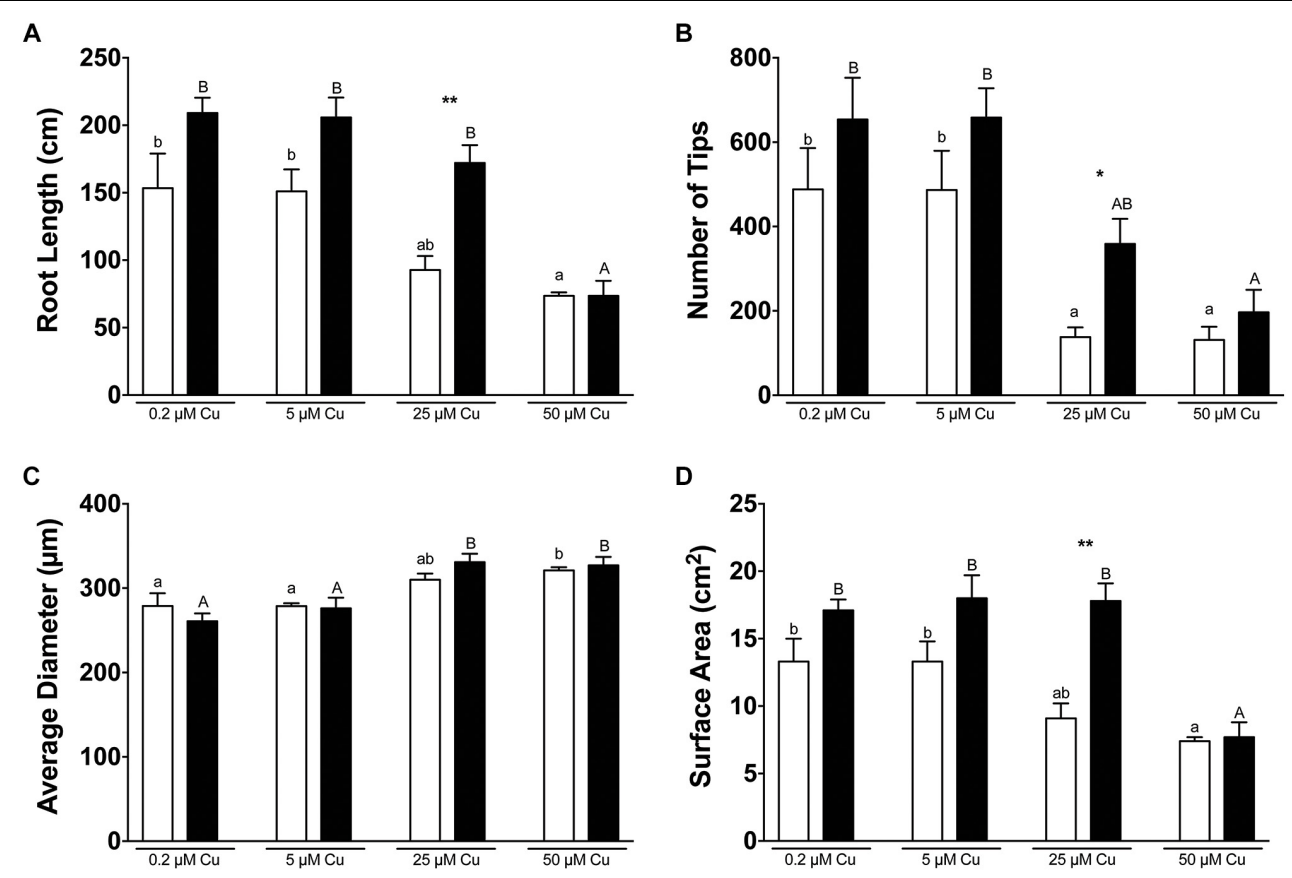

Fercal intercropped

196.17 intercropped

FIGURE 4 | Root architecture parameters of oat, intercropped with either Fercal or 196.17 rootstock plants, ad exposed to increasing concentration of Cu. (A) Total root length. (B) Total number of tips. (C) Average diameter. (D) Total surface area. Data have been collected at harvest (14 days after Cu treatment) and are reported as means $( \pm \mathrm{SE}), n=5$. Different letters indicate significantly different values as determined using one-way ANOVA with Tukey post hoc tests $(p<0.05)$. Lower-case letters account for statistical analyses of oat plants intercropped with Fercal rootstock plants and exposed to different Cu concentrations. Upper-case letters account for statistical analyses of oat plants intercropped with Fercal rootstock plants and exposed to different Cu concentrations. Within the same Cu concentration condition, the difference between Fercal-intercropped oat and 196.17-intercropped oat was tested through a Students $t$-test $\left({ }^{*} p<0.05 ;{ }^{* *} p<0.01\right)$.

(Fercal: $+53,61,138 \%$, and 196.17: $+10,26,96 \%$, vs. the control at 5,25 , and $50 \mu \mathrm{M}$, respectively).

Comparing the two growing conditions, i.e., monocropping and intercropping, a reduction in $\mathrm{Cu}$ accumulation might be inferred, at least in some cases (Figure 5). In detail, for the Fercal plants, the reduction resulted significant only in the root tissues and only for the intermediate $\mathrm{Cu}$ concentrations applied (5 and $25 \mu \mathrm{M})$. For the intercropped 196.17 rootstock, a reduction of root $\mathrm{Cu}$ concentration was observed only at 5 and $50 \mu \mathrm{M} \mathrm{Cu}$ compared to the control, whereas at $0.2 \mu \mathrm{M} \mathrm{Cu}$ intercropped plants displayed a higher $\mathrm{Cu}$ concentration compared to the monocropped 196.17 (Figure 5).

\section{CTr Genes Expression}

The components of the $V v C T r$ gene family were already identified by Martins et al. (2012a,b) in V. vinifera genome. The expression analyses of the $C \operatorname{Tr}$ genes revealed that, at $0.2 \mu \mathrm{M}$ of $\mathrm{Cu}$, the most expressed genes are the $V v C \operatorname{Tr} 1, V v C T r 2$, and $V v C \operatorname{Tr} 3$ in roots of the Fercal rootstock, and the $V v C T r 1$ and $V v C T r 3$ in the roots of the 196.17 rootstock (Supplementary Figure S3). The expression of $V v C T r 1$ increased in roots of monocropped Fercal rootstocks with increasing $\mathrm{Cu}$ concentrations, whereas it was constitutively expressed in the roots of the 196.17 rootstocks (Figures 6A, 7A). The expression of $V v C T r 1$ was up-regulated at all the $\mathrm{Cu}$ concentration, except $25 \mu \mathrm{M} \mathrm{Cu}$, in the roots of the intercropped Fercal rootstock in comparison to monocropped plants (Figure $\mathbf{6 A}$ ); on the contrary, the expression of $V v C T r 1$ was not affected by the intercropping in 196.17 rootstock at $0.2 \mu \mathrm{M} \mathrm{Cu}$, whereas it decreased with the increasing $\mathrm{Cu}$ concentrations (Figure $7 \mathrm{~A}$ ). The $\mathrm{VvCTr} 2$ expression was unchanged in the roots of monocropped Fercal rootstock, albeit a significant reduction was observed in plants grown at $50 \mu \mathrm{M} \mathrm{Cu}$ (Figure 6B). The intercropping induced a $V v C T r 2$ up-regulation at 5 and $50 \mu \mathrm{M} \mathrm{Cu}$ in Fercal plants and a gene down-regulation at $25 \mu \mathrm{M} \mathrm{Cu}$ (Figure 6B). The roots of the 196.17 rootstock did not show a high expression of the $V v C T r 2$ gene at $0.2 \mu \mathrm{M} \mathrm{Cu}$ (Supplementary Figure S3): it remained almost constant in monocropped plants, whilst it was progressively repressed with increasing $\mathrm{Cu}$ concentration in intercropped plants (Figure 7B).

In monocropped Fercal rootstocks, $V v C T r 3$ expression was reduced as compared to $V v C \operatorname{Tr} 1$, whereas an opposite trend was detected in monocropped 196.17 rootstock (Supplementary Figure S3). The increase in $\mathrm{Cu}$ concentrations induced the upregulation of $V v C T r 3$ in monocropped Fercal rootstocks, except at $50 \mu \mathrm{M} \mathrm{Cu}$ (Figure 6C), whilst it reduced the expression of $\operatorname{VvCTr} 3$ in the roots of monocropped 196.17 rootstocks (Figure 7C). The intercropping strongly induced the expression 

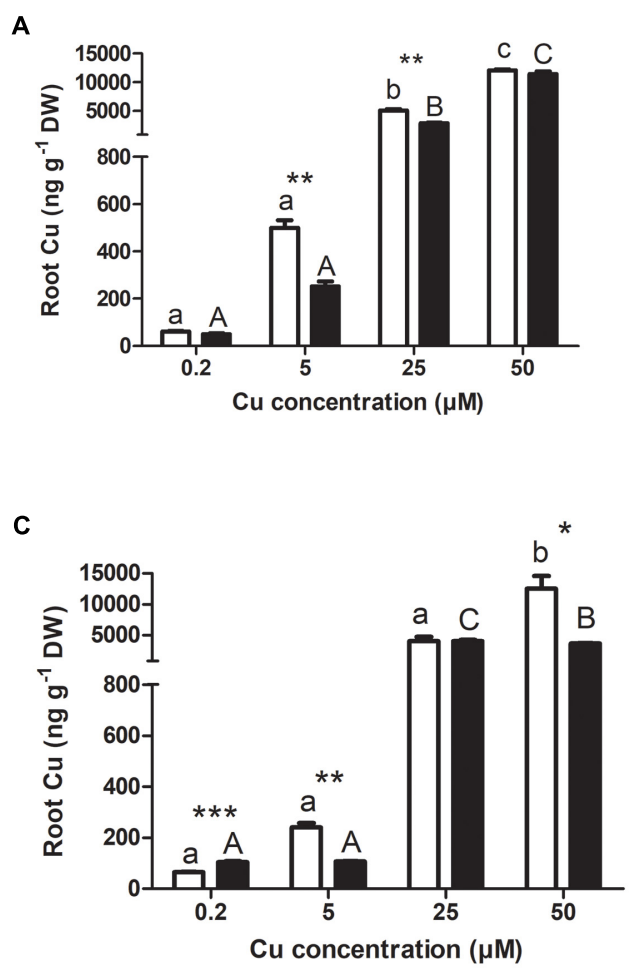

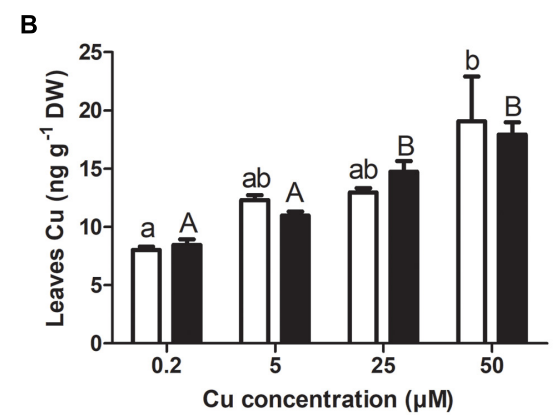

D

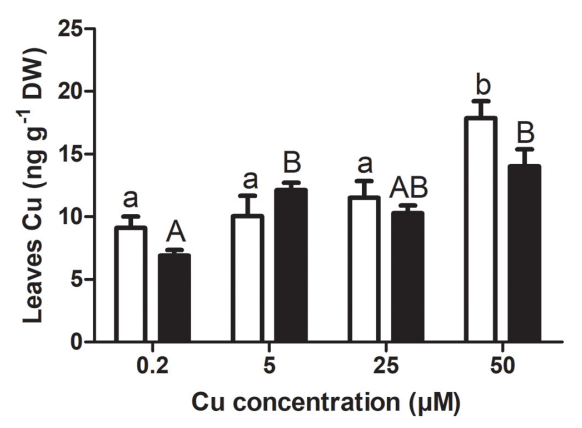

$=$ Intercropped

FIGURE 5 | Analyses of Cu concentration in grapevine plant tissues. Copper concentration detected in roots (A) and leaves (B) of both mono- and intercropped Fercal rootstock plants, and in roots (C) and leaves (D) of both mono- and intercropped 196.17 rootstock plants. The data are reported as means \pm SE of three biological replicates. Different letters indicate significantly different values as determined using one-way ANOVA with Tukey post hoc tests ( $p<0.05)$. Lower case letters indicate the statistical significance for monocropped plants in the different Cu concentrations, whilst upper case letters indicate the statistical significance for intercropped plants grown in the different Cu concentrations. Stars indicate the significance (Student's t-test) between the Cu concentrations detected in mono- and intercropped rootstock plants $\left({ }^{*} p<0.05 ;{ }^{* *} p<0.01 ;{ }^{* * *} p<0.001\right)$.

of $V v C T r 3$ in Fercal plants (Figure 6C); in 196.17 rootstock, the intercropping did not modify $V v C T r 3$ transcription at 0.2 and $5 \mu \mathrm{M} \mathrm{Cu}$ whilst it caused a significant reduction in the gene expression at 25 and $50 \mu \mathrm{M} \mathrm{Cu}$ compared to the same monocropped rootstock (Figure 7C). The $V v C T r 4, V v C \operatorname{Tr} 6$, and $\operatorname{VvCTr} 8$ genes were less expressed both in monocropped Fercal and 196.17 rootstocks at $0.2 \mu \mathrm{M} \mathrm{Cu}$ (Supplementary Figure S3). Their expression in monocropped Fercal plants remained low at all the $\mathrm{Cu}$ concentrations (Figures 6D-F); the intercropping induced $V v C T r 4$ at $0.2 \mu \mathrm{M}$ of $\mathrm{Cu}$ and $V v C T r 6$ and $V v C T r 8$ at $50 \mu \mathrm{M} \mathrm{Cu}$ (Figures 6D-F). The mRNA levels of $V v C \operatorname{Tr} 4, V v C \operatorname{Tr} 6$, and $V v C \operatorname{Tr} 8$ genes in 196.17 rootstock showed a conserved pattern: the intercropping induced a significant upregulation of genes at the lower $\mathrm{Cu}$ concentrations (i.e., 0.2 and $5 \mu \mathrm{M}$ ), and a strong down-regulation at the higher ones (i.e., 25 and $50 \mu \mathrm{M}$ ) (Figures 7D-F).

\section{NRAMP Genes Expression}

The NRAMP gene family has never been characterized before in $V$. vinifera genome; thus, to reach this objective, a bioinformatic approach was undertaken and six putative sequences similar to AtNRAMP and OsNRAMP have been identified. Among these, three transcripts were found to feature the characteristic 12 transmembrane domains and cluster with the members of the AtNRAMP and OsNRAMP gene family. These three transcripts were named $V v N R A M P 1$ (VIT_209s0070g00210), VvNRAMP2 (VIT_218s0001g09490), and VvNRAMP3 (VIT_207s0129g00620) because they clustered with AtNRAMP1, AtNRAMP2, and AtNRAMP3, respectively (Supplementary Figure S2).

$V v N R A M P 1$ is differentially modulated in the two different rootstocks (Figures 8A,B). Fercal plants did not modulate the transcription depending on $\mathrm{Cu}$ concentration in the hydroponic solution (Figure 8A). On the contrary, the expression of $V v N R A M P 1$ increased in roots of the 196.17 rootstock at 25 and $50 \mu \mathrm{M}$ of $\mathrm{Cu}$ (Figure 8B). When intercropped, both the rootstocks up-regulated $V v N R A M P 1$ expression at 0.2 and $5 \mu \mathrm{M} \mathrm{Cu}$ and down-regulated it at $25 \mu \mathrm{M}$ $\mathrm{Cu}$ (Figures 8A,B). At $50 \mu \mathrm{M} \mathrm{Cu}$, the transcription of $V v N R A M P 1$ was increased in roots of the intercropped Fercal rootstock and reduced in those of the intercropped 196.17 rootstock. VvNRAMP2 was only slightly modulated in 


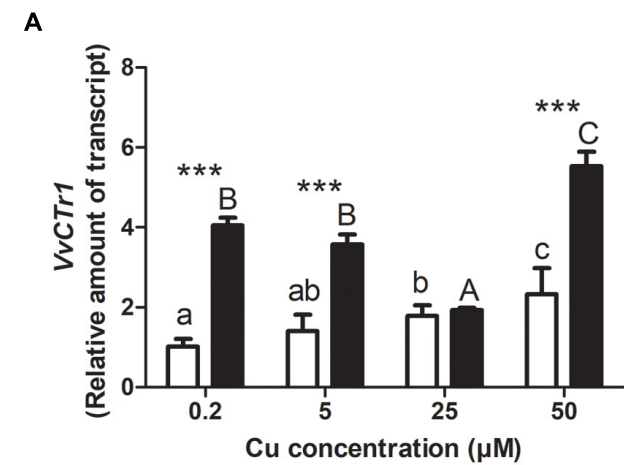

C

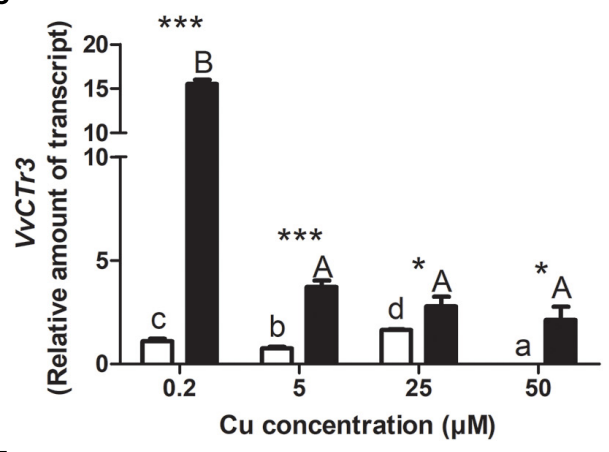

E

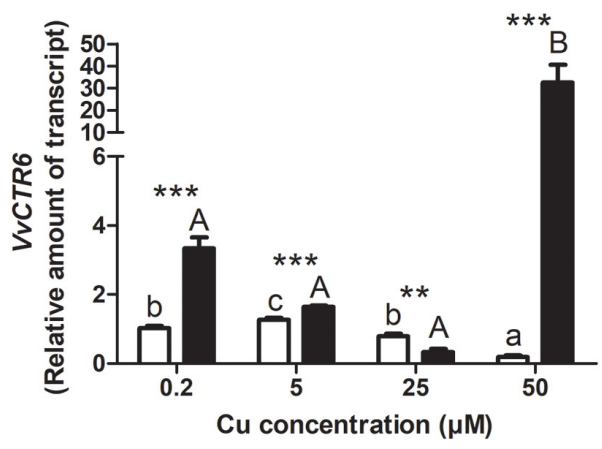

B

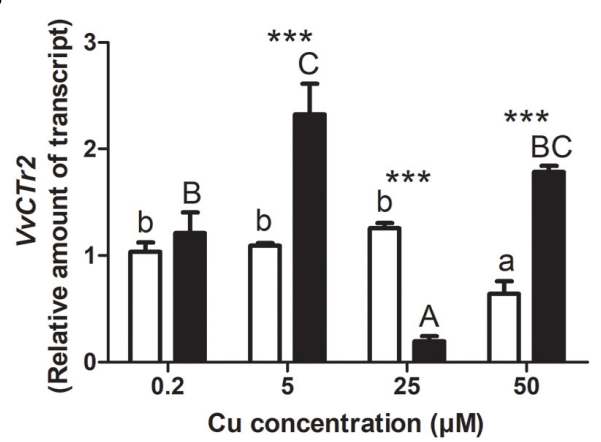

D

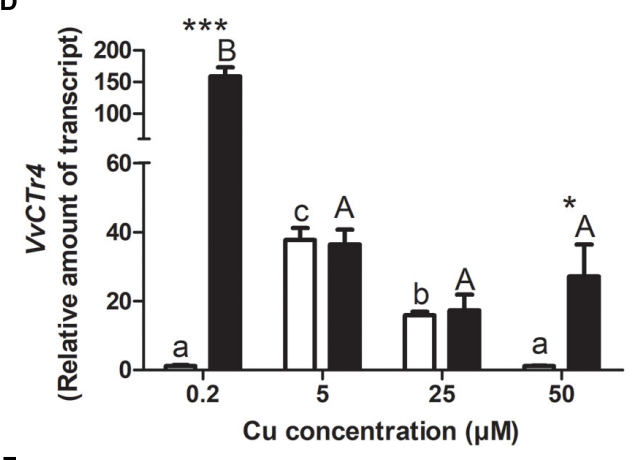

$\mathbf{F}$

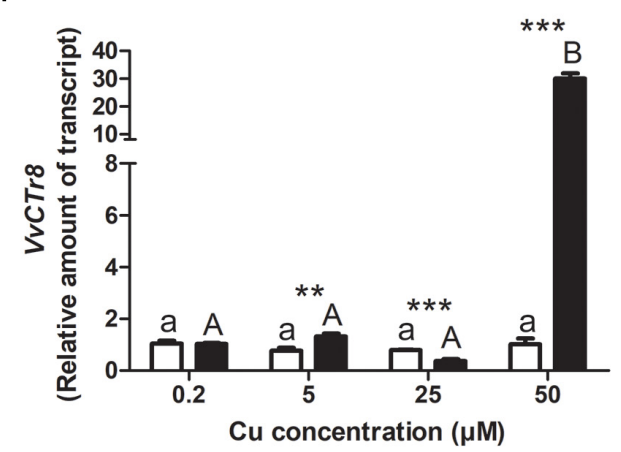

= Monocropped

$=$ Intercropped

FIGURE 6 | Quantitative real time RT-PCR analyses of $V V C T r$ genes in Fercal rootstock plants. Root apex genes expression of $V_{V} C T r 1$ (A), VVCTr2 (B), VVCTr3 (C) $V_{V C T r 4}$ (D), VVCTr6 (E), and VVCTr8 (F) determined in mono- and intercropped Fercal rootstocks. Transcripts levels are reported as relative amount of transcripts referred to the gene expression of monocropped rootstocks grown at $0.2 \mu \mathrm{M} \mathrm{Cu}$. The data are reported as means \pm SE of three biological replicates. Different letters indicate significantly different values as determined using one-way ANOVA with Tukey post hoc tests $(p<0.05)$. Lower case letters indicate the statistical significance for monocropped plants in the different Cu concentrations, whilst upper case letters indicate the statistical significance for intercropped plants grown in the different $\mathrm{Cu}$ concentrations. Stars indicate the significance (Student's $t$-test) between the gene expression of mono- and intercropped rootstocks $\left(* p<0.05\right.$; ${ }^{* *}$ $p<0.01 ; * * * 0.001)$.

roots of monocropped Fercal rootstocks with increasing $\mathrm{Cu}$ concentrations (Figure 8C). The expression of VvNRAMP2 was enhanced in roots of intercropped Fercal rootstocks at 0.2 and $5 \mu \mathrm{M} \mathrm{Cu}$, while it was reduced at 25 and $50 \mu \mathrm{M}$ $\mathrm{Cu}$ (Figure 8C). The roots of intercropped 196.17 rootstocks showed an over-expression of $V v N R A M P 2$ at $0.2 \mu \mathrm{M} \mathrm{Cu}$, no changes at 5 and $50 \mu \mathrm{M} \mathrm{Cu}$ and a down-regulation at $25 \mu \mathrm{M}$ $\mathrm{Cu}$ (Figure 8D).
VvNRAMP3 reported the same expression pattern as VvNRAMP1 for both the rootstocks and cultivation systems (Figures 8A,B,E,F).

\section{IRT Genes Expression}

The VvIRT1 has already been identified in V. vinifera genome and it was reported to be implicated in the response toward Fedeficiency conditions (Vannozzi et al., 2017). In our experimental 
A

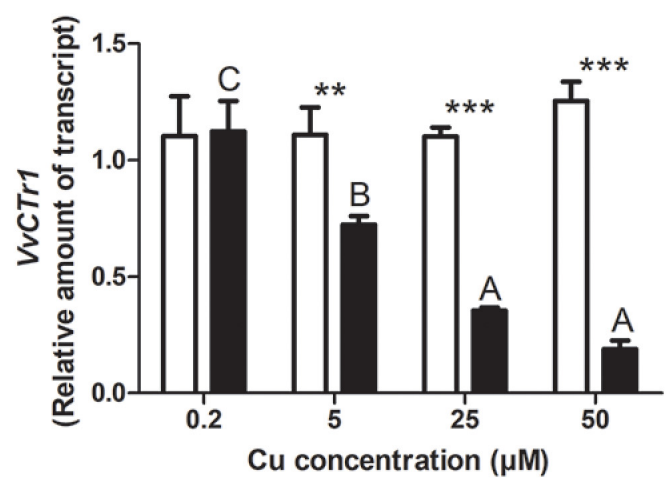

C

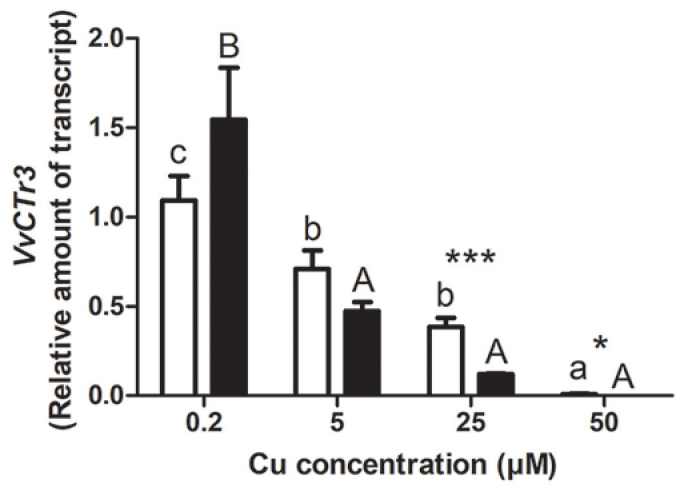

E

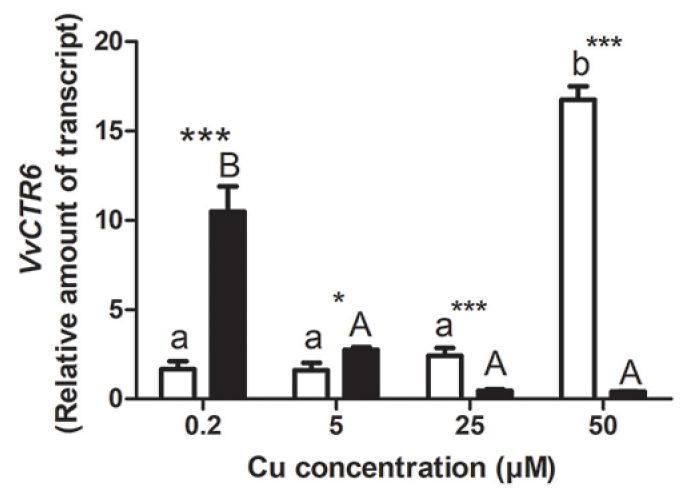

B

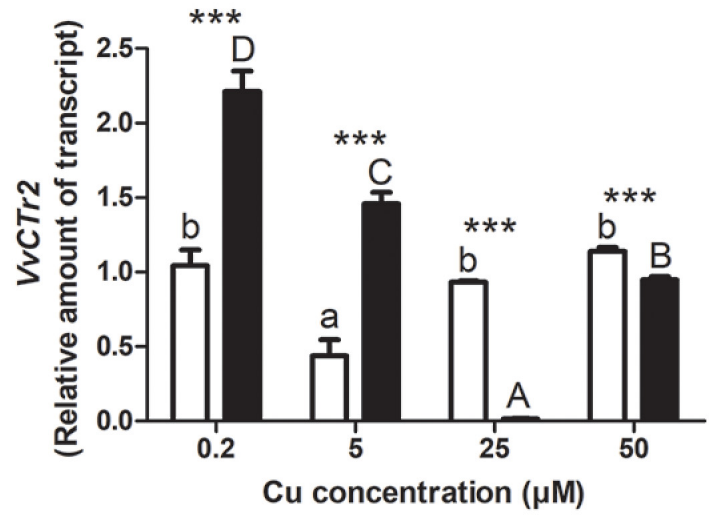

D

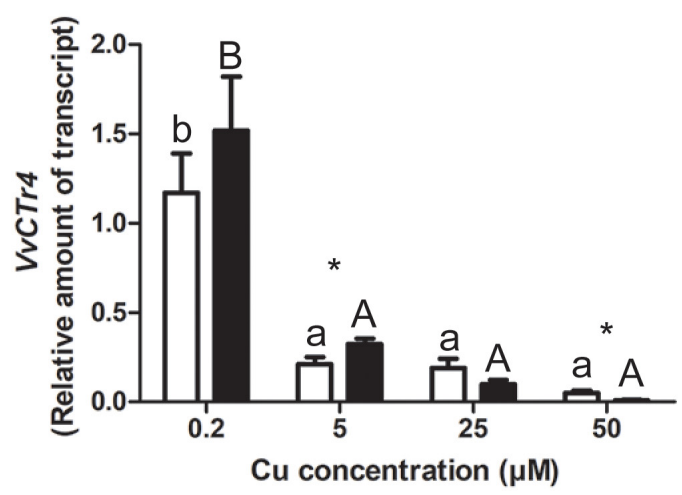

F

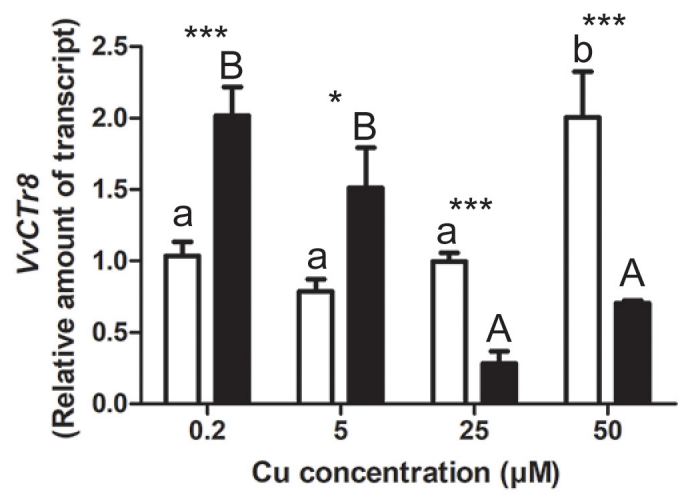

FIGURE 7 | Quantitative real time RT-PCR analyses of $V v C T r$ genes in 196.17 rootstock plants. Root apex genes expression of $V_{v} C T r 1$ (A), $V_{v} C T r 2$ (B), $V_{v} C T r 3$ (C), $V_{V} C \operatorname{Tr} 4$ (D), VvCTr6 (E), and VvCTr8 (F) determined in mono- and intercropped 196.17 rootstocks. Transcripts levels are reported as relative amount of transcripts referred to the gene expression of monocropped rootstock grown at $0.2 \mu \mathrm{M} \mathrm{Cu}$. The data are reported as means $\pm \mathrm{SE}$ of three biological replicates. Different letters indicate significantly different values as determined using one-way ANOVA with Tukey post hoc tests $(p<0.05)$. Lower case letters indicate the statistical significance for monocropped plants in the different Cu concentrations, whilst upper case letters indicate the statistical significance for intercropped plants grown in the different Cu concentrations. Stars indicate the significance (Student's $t$-test) between the gene expression of mono- and intercropped rootstocks $\left({ }^{*} p<0.05\right.$;

$* * p<0.01 ; * * * 0.001)$. 
A

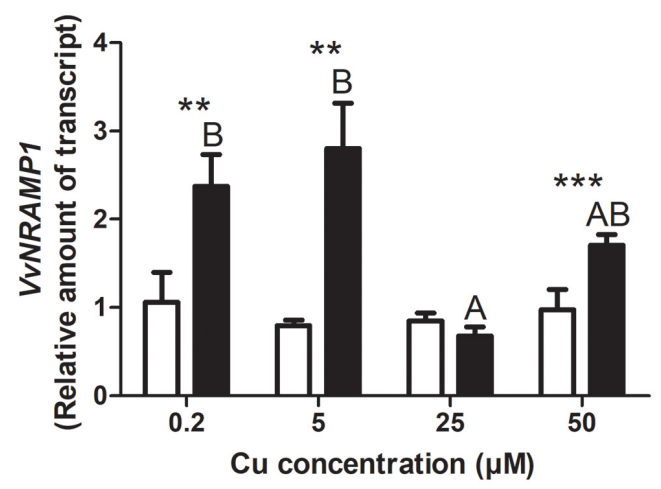

C

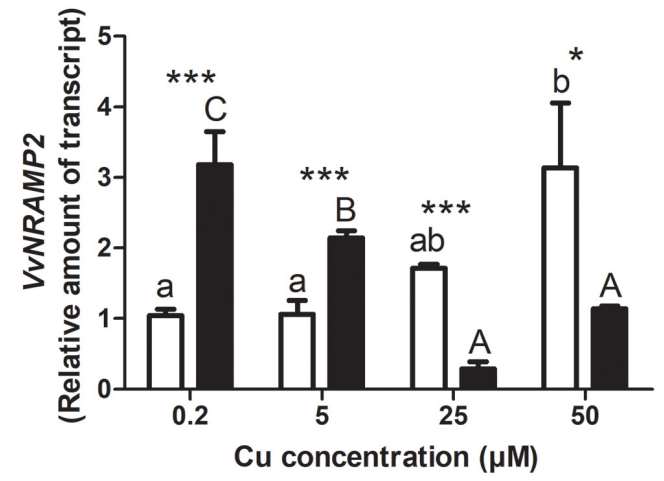

E

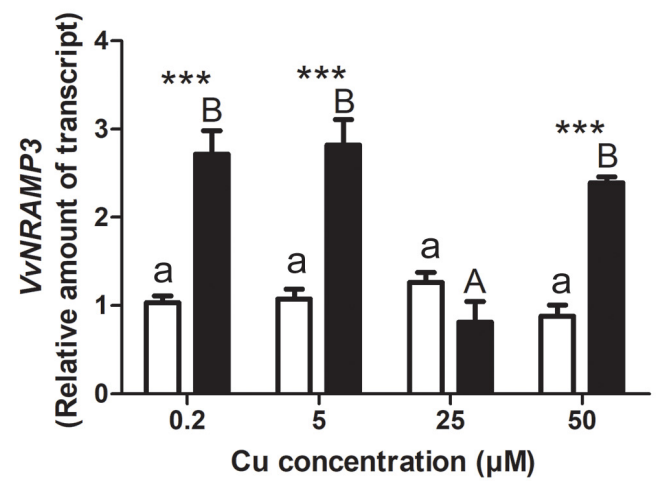

B

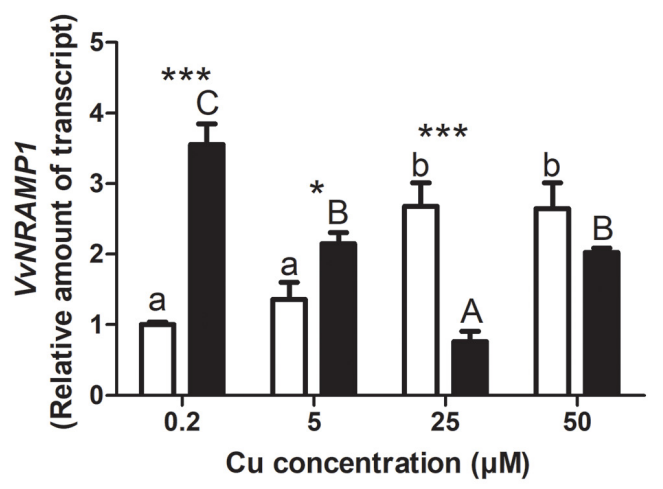

D

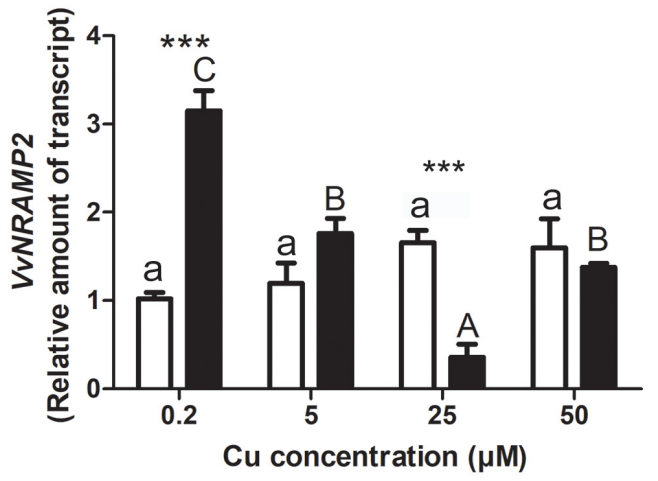

$\mathbf{F}$

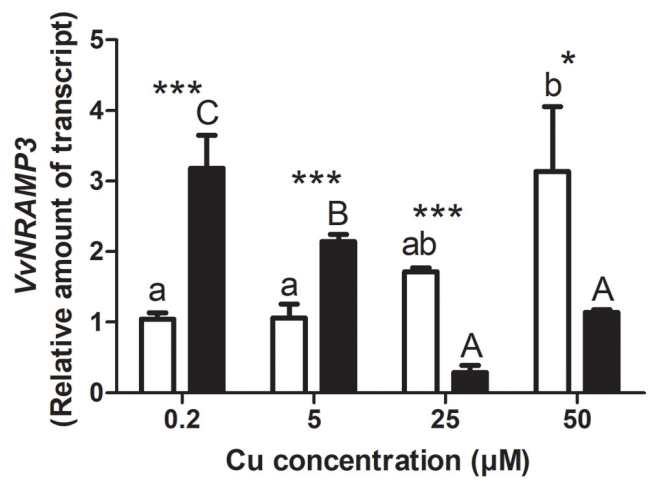

FIGURE 8 | Quantitative real time RT-PCR analyses of VVNRAMP genes in rootstock plants. Root apex genes expression of VVNRAMP1, VVNRMP2, and VVNRMP3 determined in mono- and intercropped Fercal (A,C,E) and 196.17 (B,D,F) rootstocks. Transcripts levels are reported as relative amount of transcripts referred to the gene expression of monocropped rootstock grown at $0.2 \mu \mathrm{M} \mathrm{Cu}$. The data are reported as means \pm SE of three biological replicates. Different letters indicate significantly different values as determined using one-way ANOVA with Tukey post hoc tests $(p<0.05)$. Lower case letters indicate the statistical significance for monocropped plants in the different $\mathrm{Cu}$ concentrations, whilst upper case letters indicate the statistical significance for intercropped plants grown in the different $\mathrm{Cu}$ concentrations. Stars indicate the significance (Student's $t$-test) between the gene expression of mono- and intercropped rootstocks $\left({ }^{*} p<0.05 ;{ }^{* *} p<0.01\right.$; $\left.{ }^{* * *} p<0.001\right)$. 
A

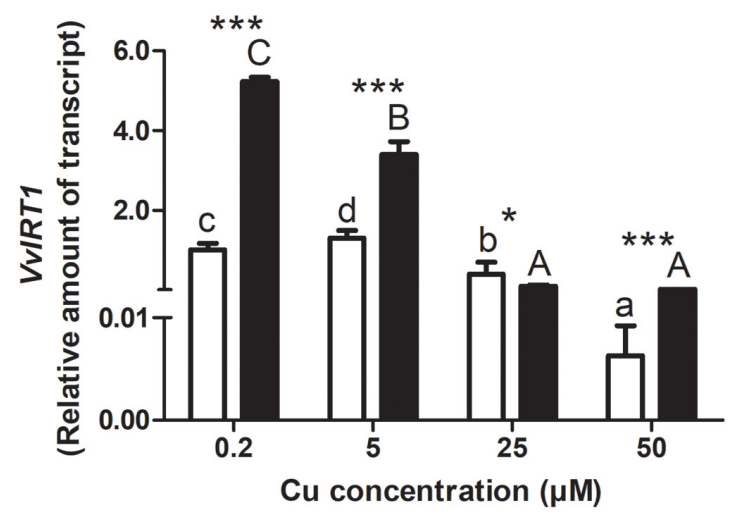

B

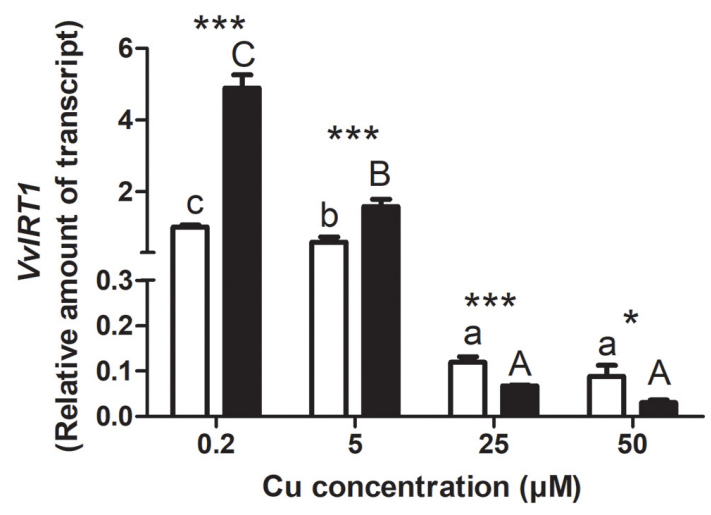

\section{$\square=$ Monocropped $\square=$ Intercropped}

FIGURE 9 | Quantitative real time RT-PCR analyses of VVIRT1 genes in rootstock plants. Root apex gene expression of VVIRT1 determined in mono- and intercropped Fercal (A) and 196.17 (B) rootstocks. Transcripts levels are reported as relative amount of transcripts referred to the gene expression of monocropped rootstock grown at $0.2 \mu \mathrm{M} \mathrm{Cu}$. The data are reported as means \pm SE of three biological replicates. Different letters indicate significantly different values as determined using one-way ANOVA with Tukey post hoc tests $(p<0.05)$. Lower case letters indicate the statistical significance for monocropped plants in the different $\mathrm{Cu}$ concentrations, whilst upper case letters indicate the statistical significance for intercropped plants grown in the different Cu concentrations. Stars indicate the significance (Student's $t$-test) between the gene expression of mono- and intercropped rootstocks $\left({ }^{*} p<0.05 ;{ }^{* *} p<0.01 ;{ }^{* * *} p<0.001\right)$.

conditions, the expression of VvIRT1 resulted down-regulated in roots of monocropped Fercal and 196.17 rootstocks with increasing $\mathrm{Cu}$ concentrations (Figures 9A,B). Intercropping led to an increased VvIRT1 expression in both rootstocks at 0.2 and $5 \mu \mathrm{M} \mathrm{Cu}$ and to a decreased expression at $25 \mu \mathrm{M} \mathrm{Cu}$. Fercal intercropped induces the expression of VvIRT1 at $50 \mu \mathrm{M} \mathrm{Cu}$ compared to the monocropped rootstock; on the contrary, the 196.17 intercropped rootstock showed a repression of VvIRT1 expression at $50 \mu \mathrm{M} \mathrm{Cu}$ (Figures 9A,B).

\section{DISCUSSION}

Different strategies and farming systems have been studied to reduce the effect of $\mathrm{Cu}$ toxicity on plants (Mackie et al., 2012). A previous study demonstrated that intercropping grapevine plants with an herbaceous species, as oat, alleviates $\mathrm{Cu}$ toxicity (Marastoni et al., 2019), yet the positive effects are rootstocktype dependent. Since $\mathrm{Cu}$ toxicity affected also the nutrient uptake, in this work we analyzed both root morphology and the transcription levels of divalent cation transporters, since both $\mathrm{Mn}$ and $\mathrm{Fe}$ have shown to have antagonistic and/or synergistic effects with $\mathrm{Cu}$ in two grapevine rootstocks (Fercal and 196.17; Marastoni et al., 2019). For this study, Fercal and 196.17 rootstocks were chosen since they are obtained from the same parental cross (i.e., Vitis vinifera $\times$ Vitis berlandieri), yet being selected for different adaptation strategies to diverse soil conditions. In particular, Fercal displays a high tolerance to active lime in the soil (i.e., alkaline soils), whereas 196.17 performs better in acidic soils, featuring very low active lime (see footnote 1). Interestingly, in these two dramatically different $\mathrm{pH}$ conditions of the soils, also the availability of $\mathrm{Cu}$ is influenced, implying that the two rootstocks might feature diverse tolerance strategies to excessive $\mathrm{Cu}$ concentrations in the growth substrate.

\section{Root Architecture of Mono- and Intercropped Rootstocks}

At root level, grapevine plants showed a phenotype that might be ascribable to $\mathrm{Cu}$ toxicity symptoms. In fact, both mono- and intercropped Fercal and 196.17 rootstocks reduced theirs shoot and root growth, and roots became darker with increasing $\mathrm{Cu}$ concentration (Figures 1, 2). Moreover, the bumping of the root tips was observed in both rootstocks and growing conditions at high $\mathrm{Cu}$ concentration (25 and $50 \mu \mathrm{M}$ Cu; Supplementary Figure S1). The thickening of the root apex was already reported in grapevine plants grown at high $\mathrm{Cu}$ concentrations (Ambrosini et al., 2015). The same authors also observed a reduced root growth as result of an inhibition of cell division at the root apex (Ambrosini et al., 2015). Accordingly, both mono- and intercropped Fercal plants reduced their root length at 25 and $50 \mu \mathrm{M} \mathrm{Cu}$ (Figure 3A), whereas the increasing $\mathrm{Cu}$ concentrations did not significantly alter the root length of the 196.17 rootstock in both growing conditions (Figure $\mathbf{3 A}$ ), thus suggesting a rootstock-dependent sensitivity to root length modifications (Figure 3). The same has been observed for the number of tips and the surface area. Comparing the two intercropped rootstocks, they had a different root length and surface area. Indeed, intercropped Fercal rootstocks had a higher root length and surface area compared to the intercropped 196.17 rootstocks. A larger root apparatus could be considered a mechanism to overcome metal toxicity and the induced nutrient deficiency, 
since it allows plants to accumulate higher concentrations of metal ions in root apoplast (Horst et al., 2010) and to explore a bigger soil volume, respectively. As already hypothesized in Marastoni et al. (2019), the data hereby presented demonstrate that Fercal is well adapted to grow in a competing environment (i.e., direct competition with other plant species for mineral nutrients), whereas 196.17 do not properly respond to the induced nutrient deficiencies. Fercal accumulates more $\mathrm{Cu}$ in its root tissues compared to the 196.17 (Figures 5A,C) and the intercropping reduces the root $\mathrm{Cu}$ concentration (Figures $\mathbf{5 A}, \mathbf{C}$ ).

\section{Gene Expression in Monocropped Grapevine Rootstocks}

To better clarify this phenomenon, it was necessary to study how the different growing conditions could affect the expression of $V v C t r, V v N R A M P$, and VvIRT1 transporter genes. Both rootstocks expressed the genes $V v C T r 2$ and $V v C T r 3$ (Figure 6) that cluster with AtCOPT1 (Martins et al., 2012a), which has been shown to be mainly expressed at the root apex in A. thaliana and likely playing a role in $\mathrm{Cu}$ uptake (Puig, 2014). Considering the expression pattern of $V v C T r 2$ and $V v C T r 3$, it could be hypothesized that $V v C \operatorname{Tr} 2$ and $V v C T r 3$ might be involved in the $\mathrm{Cu}$ uptake in Fercal and 196.17 rootstocks, respectively. Furthermore, roots of monocropped Fercal rootstocks do not modulate $V v C T r 2$ with increasing $\mathrm{Cu}$ concentration (i.e., 5 and $25 \mu \mathrm{M} \mathrm{Cu}$ ) (Figure 6B), whereas $\operatorname{VvCTr3}$ is down-regulated in roots of monocropped 196.17 rootstocks with increasing $\mathrm{Cu}$ concentrations (Figure 7C). However, regardless $\mathrm{VvCTr}$ genes expressions, the $\mathrm{Cu}$ concentration increased in both monocropped rootstocks root tissues (Figures 5A,C). This might suggest that $\mathrm{Cu}$, beside $V v C T r$ transporters, can use other mediators to reach the root symplast; indeed, VvNRAMP and VvIRT1 could thereby be valuable candidates to transport $\mathrm{Cu}$. Three members of the VvNRAMP gene family have been identified in this work; among them, $V v N R A M P 1$ clustered with AtNRAMP1 (Supplementary Figure S2), which has been reported to take up both $\mathrm{Mn}$ and $\mathrm{Fe}$ and has been identified as the only transporter of Mn in A. thaliana (Cailliatte et al., 2010). VvNRAMP2 clustered with AtNRAMP2 (Supplementary Figure S2), which is localized in the Trans-Golgi (Gao et al., 2018), whereas VvNRAMP3 clustered with AtNRAMP3 and AtNRAMP4 (Supplementary Figure S2), which are located at the tonoplast (Lanquar et al., 2005). Consequently, the phylogenetic analysis suggested that $V v N R A M P 1$ could be the transporter involved in $\mathrm{Mn}$ uptake and potentially implicated in $\mathrm{Cu}$ (II) uptake. Whilst VvNRAMP1 is not modulated in roots of monocropped Fercal rootstocks with increasing $\mathrm{Cu}$ concentrations (Figure 8A), roots of monocropped 196.17 rootstocks increased VvNRAMP1 expression at 25 and $50 \mu \mathrm{M} \mathrm{Cu}$ (Figure 8B). This up-regulation is most likely due to a $\mathrm{Cu}$-induced $\mathrm{Mn}$ deficiency in the root apoplast (Marastoni et al., 2019). Since a synergistic relationship of Fe with $\mathrm{Cu}$ has been reported (Marastoni et al., 2019), we also studied the transcriptional modulation of VvIRT1 in our experimental model. VvIRT1 expression decreased in both monocropped rootstocks at high $\mathrm{Cu}$ concentrations (25 and $50 \mu \mathrm{M} \mathrm{Cu}$; Figures 9A,B). The reduction of $V v I R T 1$ expression could be induced to prevent Fe toxicity due to the high root Fe concentrations reported for both rootstocks (Marastoni et al., 2019). A study carried out on A. thaliana plants revealed that $\mathrm{Mn}$ deficiency could induce a down regulation of AtIRT1 with an increase of root Fe concentration (Yang et al., 2008). Cailliatte et al. (2010) also reported that Mn deficiency could induce AtNRAMP1, albeit being its modulation slow. Moreover, they also demonstrated that $\mathrm{Fe}$ can be transported also by AtNRAMP1 (Cailliatte et al., 2010). A similar gene modulation pattern was observed here in the roots of 196.17 rootstocks and this is in good agreement with previous ionomic study that reported an increase in $\mathrm{Fe}$ concentration in the root tissues of plants grown in the same conditions (Marastoni et al., 2019). Consequently, we could hypothesize that the 196.17 rootstocks reduce the expression of $V v C T r 3$ when exposed to high $\mathrm{Cu}$ concentrations. Based on these observation, we develop an hypothetical uptake model for bivalent cation $(\mathrm{Cu}, \mathrm{Fe}$, and $\mathrm{Mn}$ ) in monocropped grapevines (Figure 10A): the low $\mathrm{Mn}$ concentration in the root apoplast (Marastoni et al., 2019) could be perceived as a reduced Mn availability that can firstly downregulate VvIRT1 expression in monocropped 196.17 as reported in A. thaliana (Yang et al., 2008). This could be a possible consequence of the high $\mathrm{Fe}$ concentration in root symplast (Marastoni et al., 2019). Secondly, the Cu-induced Mn deficiency could induce VvNRAMP1 at high Cu concentrations. Differently, Fercal rootstocks do not modulate $V v C T r 2$ and $V v N R A M P 1$ with increasing $\mathrm{Cu}$ concentration but down regulate VVIRT1 (Figures 6B, 8A, 9A). These different expression patterns could corroborate the better performance of the 196.17 rootstock at high $\mathrm{Cu}$ concentrations compared to the Fercal rootstock. Indeed the two rootstocks have the same parental grapevines (Vitis vinifera $\times$ Vitis berlanderi) and have been selected to grow in acidic (196.17) and calcareous (Fercal) soils (Pavloušek, 2013). The available fraction of nutrients, especially the cationic micronutrients, is dependent on soil $\mathrm{pH}$. Therefore, specifically in monocropping systems, 196.17 could be expected to better manage high level of $\mathrm{Cu}$, in terms of a lower accumulation of metal at root level, and the induced nutrient unbalances (Mn deficiency). On the contrary, Fercal is adapted to grow in soil with low nutrient availability, thus preferring the upregulation of micronutrients uptake rather than the response to $\mathrm{Cu}$ toxicity. Indeed, Fercal accumulates high concentration of $\mathrm{Cu}$ in the root tissues.

\section{Gene Expression in Intercropped Grapevine Rootstocks}

Intercropped grapevines showed a different behavior depending on the $\mathrm{Cu}$ toxicity (i.e., low - $5 \mu \mathrm{M}$, medium - $25 \mu \mathrm{M}$, and high - $50 \mu \mathrm{M})$. At $5 \mu \mathrm{M} \mathrm{Cu}$, intercropped Fercal showed the over-expression of $V v C T r 2, V v N R A M P 1$, and $V v I R T 1$ (Figures 6B, 8A, 9A) that might be ascribable to a possible nutrient competition with oat (Figure 10B). At $50 \mu \mathrm{M} \mathrm{Cu}$, intercropped Fercal induced $V v C T r 2$ expression compared to the monocropped Fercal. Moreover, VvNRAMP1 and VvIRT1 are induced at high $\mathrm{Cu}$ concentrations (Figures 8A, 9A). However, it has been shown that at $50 \mu \mathrm{M} \mathrm{Cu}$ the apoplastic 


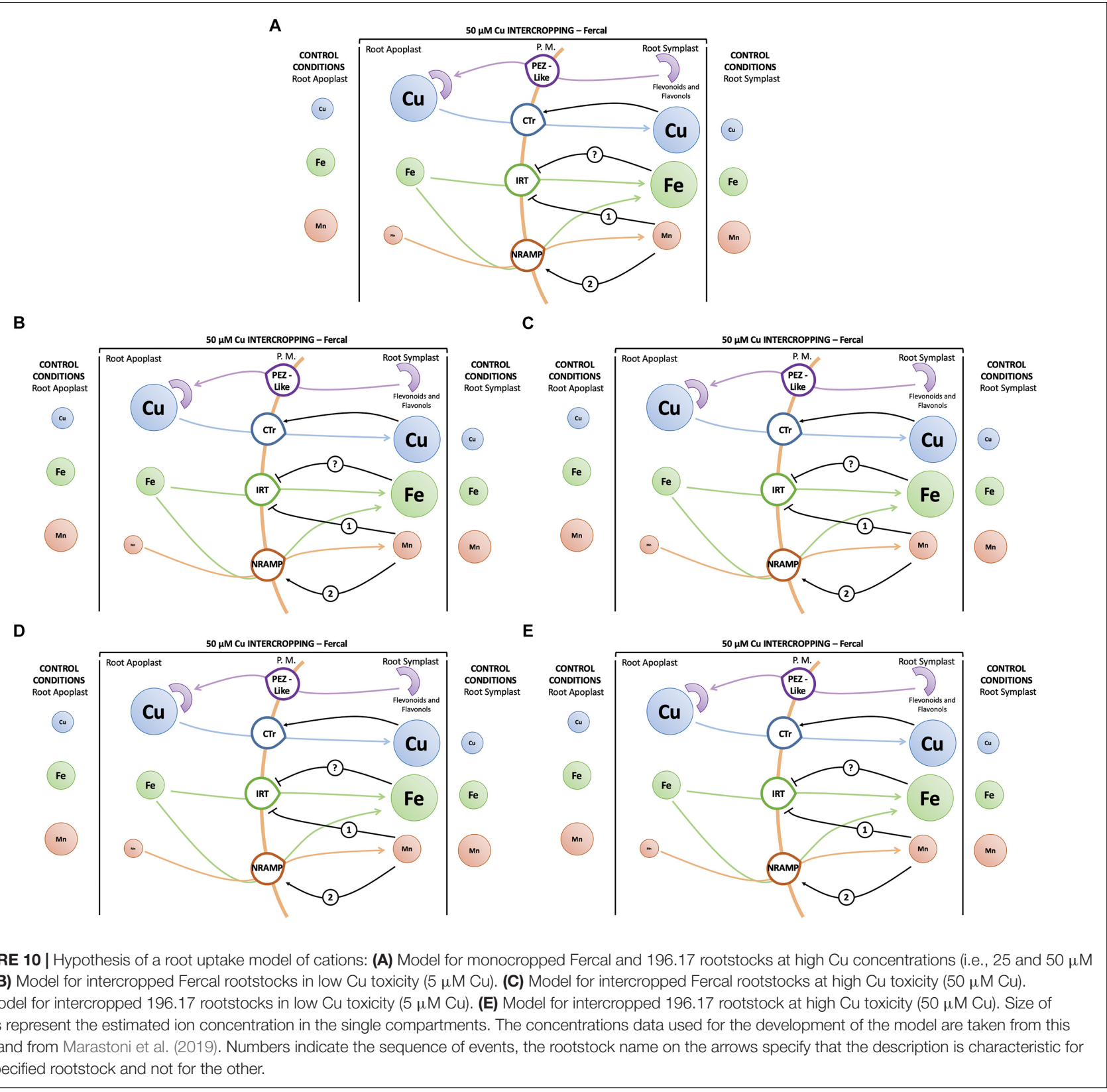

Mn concentration in intercropped Fercal is not detectable and it is lower than in the monocropping growing condition (Marastoni et al., 2019); such drop in the Mn concentration might induce a Mn-deficincy-like response thus causing the enhancement of VvNRAMP1 expression. These observations might suggest that Fercal rootstock cannot cope with $\mathrm{Cu}$ toxicity and $\mathrm{Cu}$-induced $\mathrm{Mn}$ deficiency at the same time, thus preferring the up-regulation of cationic transporters to take up $\mathrm{Mn}$ rather than the down-regulation of $V v C T r 2$ to avoid $\mathrm{Cu}$ toxicity. However, it has been demonstrated that Fercal also upregulates the VvPEZ-like genes releasing higher concentration of phenolic compounds when intercropped with oat, indicating that Fercal might adopt an external detoxification strategy (Marastoni et al., 2019; Figure 10C).
At low $\mathrm{Cu}$ concentrations $(0.2$ and $5 \mu \mathrm{M})$, intercropped 196.17 rootstocks have shown to accumulate more cations in the root apoplast than the monocropped ones (Marastoni et al., 2019). This could suggest that when intercropped, the 196.17 rootstocks modify the composition of the root apoplast (e.g., the pectin methylation degree) as reported for several plants subjected to metal toxicity (Mimmo et al., 2009). At the same time, at low $\mathrm{Cu}$ concentrations, roots of the intercropped 196.17 rootstock induces the expression of $V v C \operatorname{Tr} 2$ (mostly at $5 \mu \mathrm{M} \mathrm{Cu}$ ), $V v N R A M P 1$ and $V v I R T 1$ (Figure 10D).

At high $\mathrm{Cu}$ concentrations $(50 \mu \mathrm{M})$, roots of intercropped 196.17 rootstocks down-regulated $\operatorname{VvCTr3}(p<0.0001)$, upregulated VvNRAMP1 $(p<0.0001)$ and down-regulated VvIRT1 $(p<0.0001)$. The expression pattern of roots of intercropped 
196.17 rootstocks grown at high $\mathrm{Cu}$ concentrations is equal to the one detected in roots of the monocropped 196.17 rootstock grown at the same $\mathrm{Cu}$ concentration (Figures 10A,E). Indeed the nutrient content was shown to be similar between mono- and intercropped 196.17 rootstocks: they are both characterized by high root $\mathrm{Cu}$ concentration (Figure 4), high Fe symplast content and low Mn apoplast concentration (Marastoni et al., 2019).

\section{CONCLUSION}

In conclusion, our results demonstrate that the different adaptation of the two rootstocks to $\mathrm{Cu}$ toxicity is mainly achieved through a fine-tuning of morphological responses and bivalent cations transporter genes expression in the roots. Indeed, the enhanced root apparatus observed in Fercal rootstocks could be considered a mechanism to tolerate copper toxicity and the induced nutrient deficiency, since it allows plants to accumulate higher concentrations of metal ions in root apoplast and to explore a bigger soil volume, respectively. The 196.17 upregulates the divalent cations transporters as a consequence of a possible $\mathrm{Cu}$-induced $\mathrm{Mn}$ deficiency, whereas the Fercal rootstock does not respond to $\mathrm{Cu}$ toxicity at a molecular level. The intercropping between oat and grapevine seems to have a different effect depending on the rootstock and the $\mathrm{Cu}$ concentration in the nutrient solution. At low $\mathrm{Cu}$ concentrations (i.e., 0.2 and $5 \mu \mathrm{M} \mathrm{Cu}$ ) both rootstocks up-regulate the transporters of bivalent cations, however, the 196.17 seems also to increase the apoplast affinity for divalent cations. Moreover, the intercropped 196.17 had a lower root length and surface area. Overall, these pieces of information suggest that, in a competing environment and without metal toxicity, Fercal rootstock explore the surrounding media (i.e., higher root surface), and induce the transporters of cations. Whereas, the 196.17 rootstock competes with the other species, increasing its ability to accumulate cations in the apoplast and inducing cation transporters. At $50 \mu \mathrm{M} \mathrm{Cu}$, no differences between the root morphology of the two rootstocks were reported. However, at this $\mathrm{Cu}$ concentration Fercal induces the expression of $V v C t r 2$ suggesting that this rootstock does not use other strategies to manage $\mathrm{Cu}$ toxicity and Mn deficiency at the same time, whereas the 196.17 intercropped only up-regulate VvNRAMP1 due to the Mn deficiency.

Overall, our results could impact the agronomic practice in viticulture, since the evidence provided with the present experiments show that the choice of specific rootstock

\section{REFERENCES}

Adrees, M., Ali, S., Rizwan, M., Ibrahim, M., Abbas, F., Farid, M., et al. (2015). The effect of excess copper on growth and physiology of important food crops: a review. Environ. Sci. Pollut. Res. 22, 8148-8162. doi: 10.1007/s11356-0154496-5

Al Khateeb, W., and Al-Qwasemeh, H. (2014). Cadmium, copper and zinc toxicity effects on growth, proline content and genetic stability of Solanum nigrum L., a crop wild relative for tomato; comparative study. Physiol. Mol. Biol. Plants 20, 31-39. doi: 10.1007/s12298-013-0211-5

Ambrosini, V. G., Rosa, D. J., Corredor Prado, J. P., Borghezan, M., Bastos de Melo, G. W., Fonsêca, et al. (2015). Reduction of copper phytotoxicity by liming: genotype according with the soil conditions (e.g., heavy metal concentrations) might play an important role in the growth and the general health status of grapevine plants, that will eventually impact the productivity of the vineyard.

\section{DATA AVAILABILITY}

The raw data supporting the conclusions of this manuscript will be made available by the authors, without undue reservation, to any qualified researcher.

\section{AUTHOR CONTRIBUTIONS}

LM, YP, SC, and TM designed the study. LM, MS, and FV performed the study. All authors analyzed the data, collected, and interpreted the data. LM, YP, FV, SC, and TM wrote the manuscript.

\section{FUNDING}

This research was supported by grants from the Free University of Bozen-Bolzano (CRC projects GRASP - TN2053, and RHIZOPRO - TN2081).

\section{SUPPLEMENTARY MATERIAL}

The Supplementary Material for this article can be found online at: https://www.frontiersin.org/articles/10.3389/fpls.2019.00946/ full\#supplementary-material

FIGURE S1 | Representative root apparatus of the Fercal rootstocks at $25 \mu \mathrm{M} \mathrm{Cu}$ (a) showing the characteristic thickening of root tips caused by Cu toxicity (b). A representative root tip of a Fercal rootstock grown without toxic $\mathrm{Cu}$ concentrations (i.e., $0.2 \mu \mathrm{M} \mathrm{Cu}$ ) is also shown (b).

FIGURE S2 | Phylogenetic tree of NRAMP genes.

FIGURE S3 | VvCTr genes expression determined in root apexes of monocropped Fercal (a) and 196.17 (b) rootstocks plants grown at $0.2 \mu \mathrm{M} \mathrm{Cu}$. The data were normalized to two internal controls, the Elongation Factor $1 \alpha$ and the tubulin. The relative expression ratios were calculated using $V_{v} C T r 1$ as calibrator. The values reported are means $\pm \operatorname{SE}(n=3)$.

TABLE S1 | Sequences of primers used for the qRT-PCR.

a study of the root anatomy of young vines (Vitis labrusca L.). Plant Physiol. Biochem. 96, 270-280. doi: 10.1016/j.plaphy.2015.08.012

Baldi, E., Miotto, A., Ceretta, C. A., Quartieri, M., Sorrenti, G., Brunetto, G., et al. (2018). Soil-applied phosphorous is an effective tool to mitigate the toxicity of copper excess on grapevine grown in rhizobox. Sci. Hortic. 227, 102-111. doi: 10.1016/j.scienta.2017.09.010

Bravin, M. N., Le Merrer, B., Denaix, L., Schneider, A., and Hinsinger, P. (2010). Copper uptake kinetics in hydroponically-grown durum wheat (Triticum turgidum durum L.) as compared with soil's ability to supply copper. Plant Soil 331, 91-104. doi: 10.1007/s11104-009-0235-3

Brooker, R. W., Bennett, A. E., Cong, W.-F., Daniell, T. J., George, T. S., Hallett, P. D., et al. (2014). Improving intercropping: a synthesis of research in 
agronomy, plant physiology and ecology. New Phytol. 206, 107-117. doi: 10. 1111/nph.13132

Cailliatte, R., Schikora, A., Briat, J. F., Mari, S., and Curie, C. (2010). Highaffinity manganese uptake by the metal transporter NRAMP1 is essential for Arabidopsis growth in low manganese conditions. Plant Cell 22, 904-917. doi: $10.1105 /$ tpc. 109.073023

Cesco, S., Rombolà, A. D., Tagliavini, M., Varanini, Z., and Pinton, R. (2006). Phytosiderophores released by graminaceous species promote $59 \mathrm{Fe}$-uptake in citrus. Plant Soil 287, 223-233. doi: 10.1007/s11104-006-9069-4

Deluisa, A., Giandon, P., Aichner, M., Bortolami, P., Bruna, L., Lupetti, A., et al. (1996). Copper pollution in Italian vineyard soils. Commun. Soil Sci. Plant Anal. 27, 1537-1548. doi: 10.1080/00103629609369651

Eckhardt, U., Mas Marques, A., and Buckhout, T. J. (2001). Two ironregulated cation transporters from tomato complement metal uptakedeficient yeast mutants. Plant Mol. Biol. 45, 437-448. doi: 10.1023/A:1010620 012803

El Azzi, D., Viers, J., Guiresse, M., Probst, A., Aubert, D., Caparros, J., et al. (2013). Origin and fate of copper in a small mediterranean vineyard catchment: new insights from combined chemical extraction and $865 \mathrm{cu}$ isotopic composition. Sci. Total Environ. 46, 91-101. doi: 10.1016/J.SCITOTENV.2013.05.058

Gao, H., Xie, W., Yang, C., Xu, J., Li, J., Wang, H., et al. (2018). NRAMP2, a trans-Golgi network-localized transporter, is required for Arabidopsis root growth under manganese deficiency. New Phytol. 217, 179-193. doi: 10.1111/ nph. 14783

Gunshin, H., Mackenzie, B., Berger, U. V., Gunshin, Y., Romero, M. F., Boron, W. F., et al. (1997). Cloning and characterization of a mammalian protoncoupled metal-ion transporter. Nature 388, 482-488. doi: 10.1038/41343

Hawkesford, M., Horst, W., Kichey, T., Lambers, H., Schjoerring, J., Møller, S. I., et al. (2012). "Functions of macronutrients," in Marschner's Mineral Nutrition of Higher Plants, ed. P. Marshner (Cambridge MA: Academic Press), 135-189.

Horst, W. J., Wang, Y., and Eticha, D. (2010). The role of the root apoplast in aluminium-induced inhibition of root elongation and in aluminium resistance of plants: a review. Ann. Bot. 106, 185-197. doi: 10.1093/aob/mcq053

Juang, K.-W., Lee, Y.-I., Lai, H.-Y., and Chen, B.-C. (2014). Influence of magnesium on copper phytotoxicity to and accumulation and translocation in grapevines. Ecotoxicol. Environ. Saf. 104, 36-42. doi: 10.1016/j.ecoenv.2014.02.008

Juang, K. W., Lee, Y. I., Lai, H. Y., Wang, C. H., and Chen, B. C. (2012). Copper accumulation, translocation, and toxic effects in grapevine cuttings. Environ. Sci. Pollut. Res. 19, 1315-1322. doi: 10.1007/s11356-011-0657-3

Korshunova, Y., Eide, D., Gregg Clark, W., Lou Guerinot, M., and Pakrasi, H. (1999). The IRT1 protein from Arabidopsis thaliana is a metal transporter with a broad substrate range. Plant Mol. Biol. 40, 37-44. doi: 10.1023/A: 1026438615520

Lanquar, V., Lelièvre, F., Bolte, S., Hamès, C., Alcon, C., Neumann, D., et al. (2005). Mobilization of vacuolar iron by AtNRAMP3 and AtNRAMP4 is essential for seed germination on low iron. EMBO J. 24, 4041-4051. doi: 10.1038/sj.emboj. 7600864

Lequeux, H., Hermans, C., Lutts, S., and Verbruggen, N. (2010). Response to copper excess in Arabidopsis thaliana: impact on the root system architecture, hormone distribution, lignin accumulation and mineral profile. Plant Physiol. Biochem. 48, 673-682. doi: 10.1016/j.plaphy.2010.05.005

Li, L., Tilman, D., Lambers, H., and Zhang, F.-S. (2014). Plant diversity and overyielding: insights from belowground facilitation of intercropping in agriculture. New Phytol. 203, 63-69. doi: 10.1111/nph.12778

Lin, C.-C., Chen, L.-M., and Liu, Z.-H. (2007). Rapid effect of cadmium on lignin biosynthesis in soybean roots. Plant Sci. 172, 632-639. doi: 10.1016/j.plantsci. 2006.11.018

Mackie, K. A., Müller, T., and Kandeler, E. (2012). Remediation of copper in vineyards a mini review. Environ. Pollut. 167, 16-26. doi: 10.1016/j.envpol.2012. 03.023

Marastoni, L., Sandri, M., Pii, Y., Valentinuzzi, F., Brunetto, G., Cesco, S., et al. (2019). Synergism and antagonisms between nutrients induced by copper toxicity in grapevine rootstocks: monocropping vs. intercropping. Chemosphere 214, 563-578. doi: 10.1016/j.chemosphere.2018.09.127

Martins, V., Bassil, E., Hanana, M., Blumwald, E., and Gerós, H. (2014). Copper homeostasis in grapevine: functional characterization of the Vitis vinifera copper transporter 1. Planta 240, 91-101. doi: 10.1007/s00425-014-2067-5
Martins, V., Hanana, M., Blumwald, E., and Gerós, H. (2012a). Copper transport and compartmentation in grape cells. Plant Cell Physiol. 53, 1866-1880. doi: $10.1093 / \mathrm{pcp} / \mathrm{pcs} 125$

Martins, V., Teixeira, A., Bassil, E., Hanana, M., Blumwald, E., and Gerós, H. (2012b). Copper-based fungicide bordeaux mixture regulates the expression of Vitis vinifera copper transporters. Aust. J. Grape Wine Res. 20, 451-458. doi: 10.1111/ajgw.12096

Mimmo, T., Marzadori, C., and Gessa, C. E. (2009). Does the degree of pectin esterification influence aluminium sorption by the root apoplast? Plant Soil 314, 159-168. doi: 10.1007/s11104-008-9715-0

Northfield, T. R., Sheldon, A. R., Kopittke, P. M., and Menzies, N. W. (2011). Interaction between $\mathrm{Cu}$ toxicity and $\mathrm{P}$ deficiency in soil-grown cowpea (Vigna unguiculata (L.) Walp.). Plant Soil 342, 359-367. doi: 10.1007/s11104-0100700-z

Pavloušek, P. (2013). "Tolerance to lime - induced chlorosis and drought in grapevine rootstocks," in Abiotic Stress - Plant Responses and Applications in Agriculture, eds K. Vahdati and C. Leslie (Germany: InTech), 277-305.

Persson, B., and Argos, P. (1994). Prediction of transmembrane segments in proteins utilising multiplesequence alignments. J. Mol. Biol. 237, 182-192. doi: 10.1006/jmbi.1994.1220

Pfaffl, M. W. M. W., Horgan, G. W., and Dempfle, L. (2002). Relative expression software tool (REST $\odot$ ) for group-wise comparison and statistical analysis of relative expression results in real-time PCR. Nucleic Acids Res. 30:e36. doi: 10.1093/nar/30.9.e36

Pii, Y., Alessandrini, M., Guardini, K., Zamboni, A., and Varanini, Z. (2014). Induction of high-affinity NO3- uptake in grapevine roots is an active process correlated to the expression of specific members of the NRT2 and plasma membrane H+-ATPase gene families. Funct. Plant Biol. 41, 353-365.

Provenzano, M. R., El Bilali, H., Simeone, V., Baser, N., Mondelli, D., and Cesari, G. (2010). Copper contents in grapes and wines from a mediterranean organic vineyard. Food Chem. 122, 1338-1343. doi: 10.1016/J.FOODCHEM.2010.03.103

Puig, S. (2014). Function and regulation of the plant COPT family of high-affinity copper transport proteins. Adv. Bot. 2014, 5-7.

Ramakers, C., Ruijter, J. M., Deprez, R. H. L., and Moorman, A. F. M. (2003). Assumption-free analysis of quantitative real-time polymerase chain reaction (PCR) data. Neurosci. Lett. 339, 62-66. doi: 10.1016/S0304-3940(02)01423-4

Ribolzi, O., Valles, V., Gomez, L., and Voltz, M. (2002). Speciation and origin of particulate copper in runoff water from a mediterranean vineyard catchment. Environ. Pollut. 117, 261-271. doi: 10.1016/S0269-7491(01)00274-3

Ruyters, S., Salaets, P., Oorts, K., and Smolders, E. (2013). Copper toxicity in soils under established vineyards in Europe: a survey. Sci. Total Environ. 443, 470-477. doi: 10.1016/j.scitotenv.2012.11.001

Sancenón, V., Puig, S., Mira, H., Thiele, D. J., and Peñarrubia, L. (2003). Identification of a copper transporter family in Arabidopsis thaliana. Plant Mol. Biol. 51, 577-587. doi: 10.1023/A:102234550 7112

Simões, C. C., Melo, J. O., Magalhães, J. V., and Guimarães, C. T. (2012). Genetic and molecular mechanisms of aluminum tolerance in plants. Genet. Mol. Res. 11, 1949-1957. doi: 10.4238/2012.July.19.14

Steinmetz, Z., Kenngott, K. G. J., Azeroual, M., Schäfer, R. B., and Schaumann, G. E. (2017). Fractionation of copper and uranium in organic and conventional vineyard soils and adjacent stream sediments studied by sequential extraction. J. Soils Sediments 17, 1092-1100. doi: 10.1007/s11368-0161623-y

Takahashi, R., Ishimaru, Y., Senoura, T., Shimo, H., Ishikawa, S., Arao, T., et al. (2011). The OsNRAMP1 iron transporter is involved in Cd accumulation in rice. J. Exp. Bot. 62, 4843-4850. doi: 10.1093/jxb/er r136

Takanashi, K., Shitan, N., and Yazaki, K. (2014). The multidrug and toxic compound extrusion (MATE) family in plants. Plant Biotechnol. 31, 417-430. doi: 10.5511/plantbiotechnology.14. 0904a

Thomine, S., Wang, R., Ward, J. M., Crawford, N. M., and Schroeder, J. I. (2000). Cadmium and iron transport by members of a plant metal transporter family in Arabidopsis with homology to Nramp genes. Proc. Natl. Acad. Sci. U.S.A. 97, 4991-4996. doi: 10.1073/pnas.97.9.4991 
Tsai, H.-H., and Schmidt, W. (2017). One way. Or another? Iron uptake in plants. New Phytol. 214, 500-505. doi: 10.1111/nph.14477

Vannozzi, A., Donnini, S., Vigani, G., Corso, M., Valle, G., Vitulo, N., et al. (2017). Transcriptional characterization of a widely-used grapevine rootstock genotype under different iron-limited conditions. Front. Plant Sci. 7:1994. doi: 10.3389/ fpls.2016.01994

Walker, T. S., Bais, H. P., Grotewold, E., and Vivanco, J. M. (2014). Root exudation and rhizosphere biology. Plant Physiol. 132, 44-51. doi: 10.1104/pp.102.01 9661

Wintz, H., Fox, T., Wu, Y.-Y., Feng, V., Chen, W., Chang, H.S., et al. (2003). Expression profiles of Arabidopsis thaliana in mineral deficiencies reveal novel transporters involved in metal homeostasis. J. Biol. Chem. 278, 47644-47653. doi: 10.1074/jbc.M30933 8200

Yang, T. J. W., Perry, P. J., Ciani, S., Pandian, S., and Schmidt, W. (2008). Manganese deficiency alters the patterning and development of root hairs in Arabidopsis. J. Exp. Bot. 59, 3453-3464. doi: 10.1093/jxb/ern195

Yruela, I. (2005). Copper in plants. Braz. J. Plant Physiol. 17, 145-156.
Yuan, M., Li, X., Xiao, J., and Wang, S. (2011). Molecular and functional analyses of COPT/Ctr-type copper transporter-like gene family in rice. BMC Plant Biol. 11:69. doi: $10.1186 / 1471-2229-11-69$

Conflict of Interest Statement: The authors declare that the research was conducted in the absence of any commercial or financial relationships that could be construed as a potential conflict of interest.

The handling Editor declared a past co-authorship with several of the authors YP, TM, and SC.

Copyright $\odot 2019$ Marastoni, Sandri, Pii, Valentinuzzi, Cesco and Mimmo. This is an open-access article distributed under the terms of the Creative Commons Attribution License (CC BY). The use, distribution or reproduction in other forums is permitted, provided the original author(s) and the copyright owner(s) are credited and that the original publication in this journal is cited, in accordance with accepted academic practice. No use, distribution or reproduction is permitted which does not comply with these terms. 